\title{
Web Appendix: Do Opposites Detract? Intrahousehold Preference Heterogeneity and Inefficient Strategic Savings
}

\author{
Simone Schaner*
}

June 13, 2014

\section{A Proofs}

\section{A.1 Main Results}

Before proving Proposition 1, it is useful to describe the nature of potentially optimal savings strategies more explicitly. The following two lemmas do this.

Lemma 1 At most one spouse will travel to the bank to transact in a given period.

Proof. The proof will show that any strategy that results in both spouses going to the bank cannot be optimal. Note that if the second mover saves in account $a$, she will always save so that $u^{\prime}\left(c_{1}\right)=R_{a} \delta_{B} u^{\prime}\left(c_{2}\right)$ (and must therefore only be saving at interest rate $R_{a}$ ). Now consider the options of the first mover.

First suppose the second mover only deposits savings in the joint account. Then the first mover could simply place additional savings in the joint account to satisfy $u^{\prime}\left(y_{1}-s_{1}^{A}-s_{1}^{J}-b\right)=$ $R_{J} \delta_{B} u^{\prime}\left(y_{2}+R_{A} s_{1}^{A}+R_{J} s_{1}^{J}-b\right)$. The second mover will prefer not to go back to the bank, and consumption in both periods will be higher, since at least $b$ in banking costs are saved. This is a profitable deviation.

Instead suppose the second mover deposits at least some savings in her individual account (this requires $R_{B} \geq R_{J}$ ). If $R_{B} \geq R_{A}$, the first mover could deviate and simply not go to the bank. The second mover would continue to save at interest rate $R_{B}$ - since total resources increase by at least $b$, the only way $u^{\prime}\left(c_{1}\right)=R_{a} \delta_{B} u^{\prime}\left(c_{2}\right)$ will continue to hold is if

*simone.schaner@dartmouth.edu 
consumption in both periods increases, which is a profitable deviation. Suppose instead that $R_{B}<R_{A}$. In this case the first mover could deviate by placing the value of both his and the first mover's savings, as well as $b$, in his individual account. The second mover's best response to this strategy would be to stay at home - thus, first period consumption would be unchanged while second period consumption would strictly increase. This is a profitable deviation.

Combined, these observations show that no strategy in which both spouses go to the bank can be optimal.

Lemma 2 Consider the case where $\delta_{A} \neq \delta_{B}$. Without loss of generality, let $B$ index the discount factor of the second mover. Any pure strategy, subgame perfect Nash equilibrium (PSPNE) to the savings game must involve one of the following strategies:

i. Neither spouse saves.

ii. The first mover does not save and the second mover saves in his/her individual account with $R_{B}=R_{\max }$ such that $u^{\prime}\left(c_{1}\right)=R_{\max } \delta_{B} u^{\prime}\left(c_{2}\right)$. This strategy will only be used when $R_{J}<R_{\max }$ and $R_{A}<R_{\max }$.

iii. The first mover saves in his/her individual account such that $u^{\prime}\left(c_{1}\right)=R_{A} \delta_{A} u^{\prime}\left(c_{2}\right)$. The second mover strictly prefers to stay at home. This strategy will only be used when $R_{A} \geq R_{J}$.

iv. The first mover saves in the joint account such that $u^{\prime}\left(c_{1}\right)=R_{J} \delta_{A} u^{\prime}\left(c_{2}\right)$. The second mover strictly prefers to stay at home. This strategy will only be used when $R_{J} \geq R_{A}$.

$v$. The first mover saves to the point that the second mover is indifferent between staying home and going back to the bank to reoptimize savings. When $R_{A}>R_{J}$ the first mover will only use his/her individual account. When $R_{J} \geq R_{A}$ the first mover may use just the individual account, just the joint account, or a mixture of the two.

Proof. The proof will show that any savings strategy other than those listed above cannot be optimal. First consider strategies in which the second mover saves. By Lemma 1, the first mover will not go to the bank. It follows that the second mover will make use of the highest return account available to her. Suppose that both the first and second mover have access to an account bearing $R_{\max }$. In this case the first mover could go to the bank and deposit the second mover's optimal savings plus (if $\delta_{A}>\delta_{B}$ ) or minus (if $\delta_{A}<\delta_{B}$ ) $\varepsilon$ into the high-return account. Since $b>0$, the second mover will prefer to stay at home for sufficiently small $\varepsilon$ 
and the first mover will be strictly better off. This rules out the possibility that $R_{J}=R_{\max }$, or that $R_{A}=R_{B}=R_{\max }$.

Suppose instead that $R_{A}=R_{\max }$, but $R_{J}<R_{\max }, R_{B}<R_{\max }$. Then the first mover could go to the bank and deposit the value of the second mover's optimal savings into the high-return individual account. The second mover will optimally stay home, first period consumption will stay unchanged, and second period consumption will strictly increase. Thus, this is a profitable deviation. By process of elimination, case (ii) is the only remaining scenario in which the second mover saves.

Now consider cases where only the first mover saves. Suppose that the second mover strictly prefers to stay at home. Then it must be that the first mover is saving in the account with the highest possible return (call this return $R^{*}=\max \left\{R_{A}, R_{J}\right\}$ ) such that $u^{\prime}\left(c_{1}^{*}\right)=R^{*} \delta_{A} u^{\prime}\left(c_{2}^{*}\right)$ - otherwise the first mover could reallocate $\varepsilon$ of his savings in such a way to become strictly better off. The only scenarios satisfying these requirements are (iii) and (iv).

Finally, suppose the first mover saves to the point that the second mover is indifferent between going to the bank to reoptimize savings and staying at home. This strategy must solve the following optimization problem:

$$
\begin{array}{cc}
\max _{s_{1}^{A}, s_{1}^{J}} & u\left(y_{1}-s_{1}^{A}-s_{1}^{J}-b\right)+\delta_{A} u\left(y_{2}+R_{A} s_{1}^{A}+R_{J} s_{1}^{J}-b\right) \quad \text { subject to } \\
u\left(y_{1}-s_{1}^{A}-s_{1}^{J}-b\right)+\delta_{B} u\left(y_{2}+R_{A} s_{1}^{A}+R_{J} s_{1}^{J}-b\right) \geq V_{B}\left(s_{1}^{A}\right) \\
s_{1}^{A} \geq 0, s_{1}^{J} \geq 0
\end{array}
$$

where $V_{B}\left(s_{1}^{A}\right)$ is the utility that agent two would get from paying $b$ and reoptimizing savings at the bank. $V_{B}(\cdot)$ depends on $s_{1}^{A}$, since savings in the first mover's individual account cannot be withdrawn by the second mover. In contrast, $V_{B}(\cdot)$ does not depend on $s_{1}^{J}$, since the second mover can freely access these funds once she is at the bank.

When $R_{A}>R_{J}$, the first mover will only use the individual account for an optimal indifference strategy. To see this, suppose instead that $s_{1}^{J}>0$. The first mover could simply reallocate all the joint savings to his individual account - first period consumption would stay unchanged, second period consumption would increase, and the second mover would strictly prefer to stay at home. Thus, the only remaining strategies involving indifference of the second mover are those listed in (v).

We are now prepared to move on to Proposition 1. 
Proof of Proposition 1. Suppose $\delta_{A}=\delta_{B}$. There will be a PSPNE that implements the $\left(c_{1}^{*}, c_{2}^{*}\right)$ that maximizes both agents' utility (neither spouse would have an incentive to deviate from the strategy that generates this allocation). Since we have assumed that couples never play Pareto-dominated equilibria, it must be the case that $L=0$ when a couple is perfectly matched.

To complete the proof, it is sufficient to show that $L$ will never strictly decrease as preference heterogeneity increases. The proof proceeds by contradiction: suppose that when $\Delta^{\prime}=\left|\delta_{A}^{\prime}-\delta_{B}\right|$ increases to $\Delta^{\prime \prime}=\left|\delta_{A}^{\prime \prime}-\delta_{B}\right|$ the interest rate loss decreases from $L^{\prime}>0$ to $L^{\prime \prime}$. Denote the equilibrium consumption allocation at $\Delta^{\prime}$ as $\left(c_{1}^{\prime}, c_{2}^{\prime}\right)$ and the consumption allocation at $\Delta^{\prime \prime}$ as $\left(c_{1}^{\prime \prime}, c_{2}^{\prime \prime}\right)$.

Since the preferences of the second mover are constant, optimality of the first mover's strategy requires that

$$
\delta_{A}^{\prime}\left(u\left(c_{2}^{\prime \prime}\right)-u\left(c_{2}^{\prime}\right)\right) \leq u\left(c_{1}^{\prime}\right)-u\left(c_{1}^{\prime \prime}\right) \leq \delta_{A}^{\prime \prime}\left(u\left(c_{2}^{\prime \prime}\right)-u\left(c_{2}^{\prime}\right)\right)
$$

with at least one of the inequalities being strict. (This observation uses the fact that monotonic increases in heterogeneity require either $\delta_{A}^{\prime \prime}<\delta_{A}^{\prime}<\delta_{B}$ or $\left.\delta_{A}^{\prime \prime}>\delta_{A}^{\prime}>\delta_{B}\right)$. This implies that the second mover's preference ordering is $\left(c_{1}^{*}, c_{2}^{*}\right)_{B}\left(c_{1}^{\prime}, c_{2}^{\prime}\right) \succ_{B}\left(c_{1}^{\prime \prime}, c_{2}^{\prime \prime}\right)$. The remainder of the argument will show that any savings strategy that generates $\left(c_{1}^{\prime}, c_{2}^{\prime}\right)$ cannot be part of a PSPNE.

Since $L^{\prime}>0,\left(c_{1}^{\prime}, c_{2}^{\prime}\right)$ must be generated by the use of at least one account with $R_{a}<R_{\max }$. Lemma 2 rules out the possibility that the dominated account is that of the second mover, as the second mover's account will only be used when $R_{B}=R_{\max }$.

A second possibility is that $\left(c_{1}^{\prime}, c_{2}^{\prime}\right)$ is generated by saving only in the dominated joint account. Lemma 2 shows that the first mover will only save in the joint account when $R_{A} \leq R_{J}$. In this case it must be that $R_{\max }=R_{B}$ and $\left(c_{1}^{\prime \prime}, c_{2}^{\prime \prime}\right)$ must involve either no saving at all or the second mover optimally saving in her individual account. But this would imply that $\left(c_{1}^{*}, c_{2}^{*}\right) \underset{B}{\sim}\left(c_{1}^{\prime \prime}, c_{2}^{\prime \prime}\right)$, which is a contradiction.

The final possibility is that $\left(c_{1}^{\prime}, c_{2}^{\prime}\right)$ involves the use of the first mover's dominated individual account. It must be the case that $R_{J}>R_{A}$ and $\left(c_{1}^{\prime \prime}, c_{2}^{\prime \prime}\right)$ involves use of the joint account - otherwise $\left(c_{1}^{\prime \prime}, c_{2}^{\prime \prime}\right)$ would have to involve either no saving or the second mover saving in her individual account, which we have seen is impossible. Lemma 2 also shows that the second mover must be indifferent between staying at home and going to the bank at $\left(c_{1}^{\prime}, c_{2}^{\prime}\right)$. There are two possibilities to consider:

i. The second mover is indifferent at $\left(c_{1}^{\prime}, c_{2}^{\prime}\right)$ but not $\left(c_{1}^{\prime \prime}, c_{2}^{\prime \prime}\right)$.

ii. The second mover is indifferent at both $\left(c_{1}^{\prime}, c_{2}^{\prime}\right)$ and $\left(c_{1}^{\prime \prime}, c_{2}^{\prime \prime}\right)$. 
First consider subcase (i). If the second mover is not indifferent at $\left(c_{1}^{\prime \prime}, c_{2}^{\prime \prime}\right)$, then by Lemma $2\left(c_{1}^{\prime \prime}, c_{2}^{\prime \prime}\right)$ must involve just joint savings. This implies that

$$
V_{B}\left(s_{1}^{A^{\prime}}\right)=u\left(c_{1}^{\prime}\right)+\delta_{B} u\left(c_{2}^{\prime}\right)>u\left(c_{1}^{\prime \prime}\right)+\delta_{B} u\left(c_{2}^{\prime \prime}\right)>V_{B}(0)
$$

where $V_{B}\left(s_{1}^{A^{\prime}}\right)$ is the utility agent $\mathrm{B}$ would receive from going back to the bank and reoptimizing savings given $s_{1}^{A^{\prime}}$. However, if $R_{A}<R_{J}$ it must be that $V_{B}(0)>V_{B}\left(s_{1}^{A}\right)$ - thus, this subcase is not possible.

Finally consider subcase (ii). This requires that

$$
V_{B}\left(s_{1}^{A^{\prime}}\right)=u\left(c_{1}^{\prime}\right)+\delta_{B} u\left(c_{2}^{\prime}\right)>u\left(c_{1}^{\prime \prime}\right)+\delta_{B} u\left(c_{2}^{\prime \prime}\right)=V_{B}\left(s_{1}^{A^{\prime \prime}}\right)
$$

These inequalities will only be satisfied if $s_{1}^{A^{\prime}}<s_{1}^{A^{\prime \prime}}$. If $L^{\prime \prime}<L^{\prime}$ this must mean that both joint and individual savings are higher at $\left(c_{1}^{\prime \prime}, c_{2}^{\prime \prime}\right)\left(\right.$ so $\left.\delta_{A}^{\prime \prime}>\delta_{A}^{\prime}>\delta_{B}\right)$. However, for $\left(s_{1}^{A^{\prime}}, s_{1}^{J^{\prime}}\right)$ to be a solution to (1), it must be that agent $B$ prefers to deviate for any allocation involving $s_{1}^{A}>s_{1}^{A^{\prime}}$ and $s_{1}^{J}>s_{1}^{J^{\prime}}$. This however, would imply that $\left(c_{1}^{\prime \prime}, c_{2}^{\prime \prime}\right)$ is not feasible.

Thus, there is no possible scenario in which $L^{\prime \prime}<L^{\prime}$. This completes the proof.

\section{A.2 Extension G: A Generalization to Heterogeneity in Savings Motives}

In this subsection I broaden the model to address heterogeneity in savings motives, rather than just heterogeneity in discount factors. The structure of the game is the same as in the main model, but now I consider a couple comprised of two agents, $A$ and $B$ where the utility of agent $i \in\{A, B\}$ is given by $v_{i}\left(c_{1}, c_{2}\right)=u_{i}\left(c_{1}\right)+\delta_{i} u_{i}\left(c_{2}\right)$. This allows for agents to differ in terms of both discount factors and curvature of the utility function. The first step in the analysis is to prove an analog to Lemma 1 in the main text.

Lemma G.1 At most one spouse will travel to the bank to transact in a given period.

Proof. Without loss of generality, let $B$ index the second mover. The proof will show that any strategy that results in both spouses going to the bank cannot be optimal. To that end, suppose both players are indeed saving. Note that if the second mover saves in account $a$, she will always save so that $u_{B}^{\prime}\left(c_{1}\right)=R_{a} \delta_{B} u_{B}^{\prime}\left(c_{2}\right)$ (and must therefore only be saving at interest rate $R_{a}$ ). Now consider the options of the first mover.

First suppose the second mover only deposits savings in the joint account. Then the first mover could simply place additional savings in the joint account to satisfy $u_{B}^{\prime}\left(y_{1}-s_{1}^{A}-s_{1}^{J}-b\right)=$ 
$R_{J} \delta_{B} u_{B}^{\prime}\left(y_{2}+R_{A} s_{1}^{A}+R_{J} s_{1}^{J}-b\right)$. The second mover will prefer not to go back to the bank, and consumption in both periods will be higher, since at least $b$ in banking costs are saved. This is a profitable deviation.

Instead suppose the second mover deposits at least some savings in her individual account (this requires $R_{B} \geq R_{J}$ ). If $R_{B} \geq R_{A}$, the first mover could deviate and simply not go to the bank. The second mover would continue to save at interest rate $R_{B}$ - since total resources increase by at least $b$, the only way $u_{B}^{\prime}\left(c_{1}\right)=R_{B} \delta_{B} u_{B}^{\prime}\left(c_{2}\right)$ will continue to hold is if consumption in both periods increases, which is a profitable deviation. Suppose instead that $R_{B}<R_{A}$. In this case the first mover could deviate by placing the value of both his and the first mover's savings, as well as $b$, in his individual account. The second mover's best response to this strategy would be to stay at home - thus, first period consumption would be unchanged while second period consumption would strictly increase. This is a profitable deviation.

Combined, these observations show that no strategy in which both spouses go to the bank can be optimal.

Next, I establish a generalized version of Lemma 2.

Lemma G.2 Consider the case where spouse $A$ and $B$ 's most preferred allocations do not coincide. Let $B$ index the second mover. Any pure strategy, subgame perfect Nash equilibrium (PSPNE) to the savings game must involve one of the following strategies:

i. Neither spouse saves.

ii. The first mover does not save and the second mover saves in his/her individual account with $R_{B}=R_{\max }$ such that $u_{B}^{\prime}\left(c_{1}\right)=R_{\max } \delta_{B} u_{B}^{\prime}\left(c_{2}\right)$.

iii. The first mover saves in his/her individual account such that $u_{A}^{\prime}\left(c_{1}\right)=R_{A} \delta_{A} u_{A}^{\prime}\left(c_{2}\right)$. The second mover strictly prefers to stay at home. This strategy will only be used when $R_{A} \geq R_{J}$.

iv. The first mover saves in the joint account such that $u_{A}^{\prime}\left(c_{1}\right)=R_{J} \delta_{A} u_{A}^{\prime}\left(c_{2}\right)$. The second mover strictly prefers to stay at home. This strategy will only be used when $R_{J} \geq R_{A}$.

$v$. The first mover saves to the point that the second mover is indifferent between staying home and going back to the bank to reoptimize savings. When $R_{A}>R_{J}$ the first mover will only use his/her individual account. When $R_{J} \geq R_{A}$ the first mover may use just the individual account, just the joint account, or a mixture of the two. 
Proof. The proof will show that any savings strategy other than those listed above cannot be optimal. First consider strategies in which the second mover saves. By Lemma G.1, the first mover will not go to the bank. It follows that the second mover will make use of the highest return account available to her. Suppose that $R_{A}>R_{J}$ and $R_{A}>R_{B}$. Then the first mover could go to the bank and deposit the value of the second mover's optimal savings into the high-return individual account. The second mover will optimally stay home, first period consumption will stay unchanged, and second period consumption will strictly increase. Thus, this is a profitable deviation. By process of elimination, case (ii) is the only scenario in which the second mover saves.

Now consider cases where only the first mover saves. Suppose that the second mover strictly prefers to stay at home. Then it must be that the first mover is saving in the account with the highest possible return (call this return $R^{*}=\max \left\{R_{A}, R_{J}\right\}$ ) such that $u_{A}^{\prime}\left(c_{1}^{*}\right)=R^{*} \delta_{A} u_{A}^{\prime}\left(c_{2}^{*}\right)$ - otherwise the first mover could reallocate $\varepsilon$ of his savings in such a way to become strictly better off. The only scenarios satisfying these requirements are (iii) and (iv).

Finally, suppose the first mover saves to the point that the second mover is indifferent between going to the bank to reoptimize savings and staying at home. This strategy must solve the following optimization problem:

$$
\begin{array}{ccc}
\max _{s_{1}^{A}, s_{1}^{J}} & u_{A}\left(y_{1}-s_{1}^{A}-s_{1}^{J}-b\right)+\delta_{A} u_{A}\left(y_{2}+R_{A} s_{1}^{A}+R_{J} s_{1}^{J}-b\right) \quad \text { subject to (2) } \\
u_{B}\left(y_{1}-s_{1}^{A}-s_{1}^{J}-b\right)+\delta_{B} u_{B}\left(y_{2}+R_{A} s_{1}^{A}+R_{J} s_{1}^{J}-b\right) \geq V_{B}\left(s_{1}^{A}\right) \\
s_{1}^{A} \geq 0, s_{1}^{J} \geq 0
\end{array}
$$

where $V_{B}\left(s_{1}^{A}\right)$ is the utility that agent $B$ would get from paying $b$ and reoptimizing savings at the bank. $V_{B}(\cdot)$ depends on $s_{1}^{A}$, since savings in the first mover's individual account cannot be withdrawn by the second mover. In contrast, $V_{B}(\cdot)$ does not depend on $s_{1}^{J}$, since the second mover can freely access these funds once she is at the bank.

When $R_{A}>R_{J}$, the first mover will only use the individual account for an optimal indifference strategy. To see this, suppose instead that $s_{1}^{J}>0$. The first mover could simply reallocate all the joint savings to his individual account - first period consumption would stay unchanged, second period consumption would increase, and the second mover would strictly prefer to stay at home. Thus, the only remaining strategies involving indifference of the second mover are those listed in (v).

Now the goal is to obtain a comparative static with respect to the interest rate loss and preference heterogeneity. In order to do this, we need to develop a well-defined concept of what it means to increase preference heterogeneity. As in the main text I consider changing 
the preferences of the first mover (agent $A$ ) holding the preferences of the second mover (agent $B$ ) constant. The key is to define a set of perturbations that correspond to monotonic changes in the savings preferences of agent $A$.

I define a perturbation in $A$ 's preferences to make him globally more savings oriented if the following condition holds for all $\left(c_{1}, c_{2}\right)-\left(c_{1}^{\prime}, c_{2}^{\prime}\right)$ pairs with $c_{1}>c_{1}^{\prime}$ and $c_{2}<c_{2}^{\prime}$ :

- If $\left(c_{1}, c_{2}\right) \underset{A}{\prec}\left(c_{1}^{\prime}, c_{2}^{\prime}\right)$ before the perturbation, then $\left(c_{1}, c_{2}\right) \underset{A}{\prec}\left(c_{1}^{\prime}, c_{2}^{\prime}\right)$ after the perturbation.

Analogously, I define a perturbation in A's preferences to make him globally more present oriented if the following condition holds for all $\left(c_{1}, c_{2}\right)-\left(c_{1}^{\prime}, c_{2}^{\prime}\right)$ pairs with $c_{1}>c_{1}^{\prime}$ and $c_{2}<c_{2}^{\prime}$ :

- If $\left(c_{1}, c_{2}\right) \underset{A}{\succeq}\left(c_{1}^{\prime}, c_{2}^{\prime}\right)$ before the perturbation, then $\left(c_{1}, c_{2}\right) \succ_{A}\left(c_{1}^{\prime}, c_{2}^{\prime}\right)$ after the perturbation.

Given these definitions, we can establish the following result, which parallels Proposition 1:

Proposition G.1 Consider a couple with access to interest rates $\left\{R_{A}, R_{B}, R_{J}\right\}$ who are playing a pure strategy, non Pareto dominated, subgame perfect Nash equilibrium to the savings game. Fix endowments $\left\{y_{1}, y_{2}\right\}$ and banking costs $b$, as well as the preferences of the second mover. When a couple is perfectly matched on preferences, $L=0 . L$ must increase with successive perturbations in A's preferences that make A either increasingly globally savings oriented or increasingly globally present oriented.

Proof. Begin with the case where there is no preference heterogeneity. Then there will be a PSPNE that implements the $\left(c_{1}^{*}, c_{2}^{*}\right)$ that maximizes both agents' utility (neither spouse would have an incentive to deviate from the strategy that generates this allocation). Since we have assumed that couples never play Pareto-dominated equilibria, it must be the case that $L=0$ when a couple is perfectly matched.

To complete the proof, it is sufficient to show that $L$ will never strictly decrease as preference heterogeneity increases. The proof proceeds by contradiction: first, consider a couple with identical preferences (and equilibrium consumption allocation $\left(c_{1}^{*}, c_{2}^{*}\right)$ ). First consider a perturbation that makes agent $A$ globally more savings oriented. Let $A$ 's new preferences be $\hat{v}_{A}\left(c_{1}, c_{2}\right)$, the new equilibrium consumption allocation be $\left(\hat{c}_{1}, \hat{c}_{2}\right)$, and the interest rate loss be $\hat{L}>0$. Then consider a perturbation that makes $A$ even more globally savings oriented, with preferences $\hat{\hat{v}}_{A}\left(c_{1}, c_{2}\right)$, equilibrium consumption allocation $\left(\hat{\hat{c}}_{1}, \hat{\hat{c}}_{2}\right)$, and interest rate loss $\hat{\hat{L}}$. Finally, suppose that $0 \leq \hat{\hat{L}}<\hat{L}$. 
Since the preferences of the second mover are held constant, allocations $\left(c_{1}^{*}, c_{2}^{*}\right),\left(\hat{c}_{1}, \hat{c}_{2}\right)$, and $\left(\hat{\hat{c}}_{1}, \hat{\hat{c}}_{2}\right)$ are always available to agent $A$. Since each perturbation makes $A$ globally more savings oriented, it must be that

$$
c_{1}^{*}>\hat{c}_{1}>\hat{\hat{c}}_{1} \text { and } c_{2}^{*}<\hat{c}_{2}<\hat{\hat{c}}_{2}
$$

The remainder of the argument will show that any savings strategy that generates $\left(\hat{c}_{1}, \hat{c}_{2}\right)$ cannot be part of a PSPNE.

Since $\hat{L}>0,\left(\hat{c}_{1}, \hat{c}_{2}\right)$ must be generated by the use of at least one account with $R_{a}<R_{\max }$. Lemma G.2 rules out the possibility that the dominated account is that of the second mover, as the second mover's account will only be used when $R_{B}=R_{\max }$.

A second possibility is that $\left(\hat{c}_{1}, \hat{c}_{2}\right)$ is generated by saving only in the dominated joint account. Lemma G.2 shows that the first mover will only save in the joint account when $R_{A} \leq R_{J}$. In this case it must be that $R_{\max }=R_{B}$, which further implies that $\left(\hat{\hat{c}}_{1}, \hat{\hat{c}}_{2}\right)$ must involve the second mover optimizing. This would imply that $\left(c_{1}^{*}, c_{2}^{*}\right) \underset{B}{\sim}\left(\hat{\hat{c}}_{1}, \hat{\hat{c}}_{2}\right)$. But by definition of globally more savings oriented, this would imply that at $\hat{v}_{A}\left(c_{1}, c_{2}\right),\left(\hat{\hat{c}}_{1}, \hat{\hat{c}}_{2}\right) \succ_{A}$ $\left(\hat{c}_{1}, \hat{c}_{2}\right)$, which is a contradiction.

The final possibility is that $\left(\hat{c}_{1}, \hat{c}_{2}\right)$ involves the use of the first mover's dominated individual account. It must be the case that $R_{J}>R_{A}$ and $\left(\hat{\hat{c}}_{1}, \hat{\hat{c}}_{2}\right)$ involves use of the joint account - otherwise $\left(\hat{\hat{c}}_{1}, \hat{\hat{c}}_{2}\right)$ would have to involve the second mover optimizing, which we have seen is impossible. Lemma G.2 also shows that the second mover must be indifferent between staying at home and going to the bank at $\left(\hat{c}_{1}, \hat{c}_{2}\right)$. There are two possibilities to consider:

i. The second mover is indifferent at $\left(\hat{c}_{1}, \hat{c}_{2}\right)$ but not $\left(\hat{\hat{c}}_{1}, \hat{\hat{c}}_{2}\right)$.

ii. The second mover is indifferent at both $\left(\hat{c}_{1}, \hat{c}_{2}\right)$ and $\left(\hat{\hat{c}}_{1}, \hat{\hat{c}}_{2}\right)$.

First consider subcase (i). If the second mover is not indifferent at $\left(\hat{\hat{c}}_{1}, \hat{\hat{c}}_{2}\right)$, then by Lemma G.2 $\left(\hat{\hat{c}}_{1}, \hat{\hat{c}}_{2}\right)$ must involve just joint savings. But this implies that agent $A$ would be able to transfer $\hat{s}_{1}^{A}$ to the joint account without violating agent $B$ 's reoptimization constraint, which is a contradiction.

Finally consider subcase (ii). It must be that individual savings is higher in absolute terms at $\left(\hat{\hat{c}}_{1}, \hat{\hat{c}}_{2}\right)$ - otherwise we could apply the argument used for sub-case (i). If $\hat{L}>\hat{\hat{L}}$ this must mean that both joint and individual savings are higher at $\left(\hat{\hat{c}}_{1}, \hat{\hat{c}}_{2}\right)$. However, starting from $\left(\hat{c}_{1}, \hat{c}_{2}\right)$ it is impossible to increase both $\hat{s}_{1}^{A}$ and $\hat{s}_{1}^{J}$ and satisfy $B$ 's reoptimization constraint, 
which is

$$
u_{B}\left(\hat{c}_{1}\right)+\delta_{B} u_{B}\left(\hat{c}_{B}\right)-u_{B}\left(c_{1}^{* *}\right)-\delta_{B} u_{B}\left(c_{2}^{* *}\right)=0
$$

where $\left(c_{1}^{* *}, c_{2}^{* *}\right)$ is the consumption allocation that would obtain if agent $\mathrm{B}$ were to pay $b$, travel to the bank, and reoptimize savings. To see this, note that by definition of globally more savings oriented it must be that $\hat{c}_{1}<c_{1}^{* *}$ and $\hat{c}_{2}>c_{2}^{* *}$ - otherwise $A$ 's behavior would not be optimal. The impact of increasing $s_{1}^{J}$ on the reoptimization constraint is

$$
-u_{B}^{\prime}\left(\hat{c}_{1}\right)+R_{J} \delta_{B} u_{B}^{\prime}\left(\hat{c}_{2}\right)
$$

which must be negative if $\hat{c}_{1}<c_{1}^{* *}$ and $\hat{c}_{2}>c_{2}^{* *}$. Moreover, the impact of increasing $s_{1}^{A}$ on the reoptimization constraint is

$$
u_{B}^{\prime}\left(c_{1}^{* *}\right)-u_{B}^{\prime}\left(\hat{c}_{1}\right)+R_{A} \delta_{B}\left[u_{B}^{\prime}\left(\hat{c}_{2}\right)-u_{B}^{\prime}\left(c_{2}^{* *}\right)\right]<0
$$

This implies that it is impossible to increase both $s_{1}^{A}$ and $s_{1}^{J}$ from $\left(\hat{c}_{1}, \hat{c}_{2}\right)$, which further implies that $\left(\hat{\hat{c}}_{1}, \hat{\hat{c}}_{2}\right)$ is not feasible.

Thus, there is no possible scenario in which $\hat{\hat{L}}<\hat{L}$. This completes the proof for increases in preference heterogeneity that make $A$ globally more savings oriented. A parallel line of reasoning establishes the result for the case in which $A$ is made globally more present oriented.

\section{A.3 Extension S: A Simultaneous-Move Version of the Savings Game}

Here I consider a version of the two period savings game with the following alternative setup for the within-period sequence of events:

1. The endowment, and returns on any previous-period savings are revealed.

2. Both spouses simultaneously decide whether to go the bank and if so, how much to save/withdraw from each account that they have access to. Each spouse who goes to the bank must pay banking cost $b$.

3. If savings takes place in sub-stage 2:

a. The spouses return home and observe savings choices.

b. Both spouses have the opportunity to return to the bank a second time (again at a cost $b$ ) to modify their savings choices.

4. Consumption takes place, and the period ends. 
The first task at hand is to characterize the savings strategies that may be part of a PSPNE. Note that I require actions in sub-stage $3 \mathrm{~b}$ above to be optimal responses to savings choices made in sub-stage 2 . We begin with a simultaneous move version of Lemma 1.

Lemma S.1 In any non-dominated PSPNE at most one spouse will travel to the bank to transact in a given period. This spouse will travel to the bank no more than once.

Proof. First, we can rule out the possibility that spouses save in both stages (2 and $3 \mathrm{~b}$ ) during a period. First consider the case where the proposed equilibrium involves (without loss of generality) spouse $A$ saving at stage 2 and spouse $B$ traveling to the bank during stage $3 \mathrm{~b}$. If spouse $A$ is saving at a (weakly) higher interest rate than spouse $B$, she could simply place spouse $B$ 's stage $3 \mathrm{~b}$ savings in her higher return account at stage 2 . If spouse $B$ is saving at a (weakly) higher interest rate, it would be a profitable deviation for spouse $A$ to simply not save in stage 2 . Next consider the case where the same player saves in both stages. This player could modify her behavior by implementing all her savings during stage 2 and reallocating the saved banking costs between consumption and savings in such as way as to leave her spouse's optimal strategy unchanged. Together, these insights imply that the couple will only save in stage 2 .

Next we need to rule out the possibility that both spouses save at once in stage 2 . To obtain a contradiction, suppose there exists a non-dominated PSPNE in which this is actually the case. In this case it is possible to construct a Pareto dominant PSPNE in which only the highest return account is used for saving and the resulting surplus is spread between period 1 and 2 consumption. For example, suppose both spouses are saving individually. Then it must be that $u^{\prime}\left(c_{1}\right)=R_{A} \delta_{A} u^{\prime}\left(c_{2}\right)=R_{B} \delta_{B} u^{\prime}\left(c_{2}\right)$. Note that these equalities must hold if both spouses strictly prefer to stay home during stage $3 \mathrm{~b}$. Further, note that if one spouse were indifferent between going to the bank and staying home at stage $3 \mathrm{~b}$, this would imply that his/her initial stage 2 strategy was not optimal (since returning to the bank at stage $3 \mathrm{~b}$ incurs an additional cost $b$ ) - thus, both spouses must strictly prefer to stay home at stage 3b. In this case we can construct an alternative equilibrium where the less patient spouse is the only one who saves - this would result in strictly more consumption in both periods (since banking cost $b$ is saved) and neither spouse will have an incentive to deviate from this arrangement. It is possible to construct similar arguments for all other possible scenarios.

Together, these arguments imply that any non-dominated PSPNE will involve at most one spouse saving.

Note that in the simultaneous move case, I have restricted the above lemma to refer to non-dominated PSPNE. This is because in the simultaneous move game it is possible to have Nash equilibria in which both spouses travel to the bank to save. However, these equilibria 
will either not survive the subgame perfection refinement and/or be Pareto dominated by an alternative in which only one spouse saves.

We can now characterize the strategies used in non-dominated PSPNE in more detail using an analog to Lemma 2:

Lemma S.2 Consider the case where $\delta_{A} \neq \delta_{B}$. Without loss of generality let $A$ index the spouse who saves. Then any non-dominated PSPNE to the savings game must involve one of the following strategies:

i. Neither spouse saves.

ii. Agent $A$ saves in his/her individual account such that $u^{\prime}\left(c_{1}\right)=R_{A} \delta_{A} u^{\prime}\left(c_{2}\right)$. Agent $B$ strictly prefers to stay at home. This strategy will only be used when $R_{A} \geq R_{J}$.

iii. Agent $A$ saves in the joint account such that $u^{\prime}\left(c_{1}\right)=R_{J} \delta_{A} u^{\prime}\left(c_{2}\right)$. Agent $B$ strictly prefers to stay at home. This strategy will only be used when $R_{J} \geq R_{A}$.

iv. Agent $A$ saves to the point that agent $B$ is indifferent between staying home and going to the bank. When $R_{A}>R_{J}$ agent $A$ will only use his/her individual account. When $R_{J} \geq R_{A}$ agent $A$ may use just the individual account, just the joint account, or a mixture of the two.

Proof. This proof closely tracks that of Lemma 2 - I will show that any savings strategy other than those listed above cannot be optimal.

First consider cases where agent $A$ saves and agent $B$ strictly prefers to stay at home. Then it must be that $A$ is saving in the account with the highest possible return (call this return $\left.R^{*}=\max \left\{R_{A}, R_{J}\right\}\right)$ such that $u^{\prime}\left(c_{1}^{*}\right)=R^{*} \delta_{A} u^{\prime}\left(c_{2}^{*}\right)$ - otherwise $A$ could reallocate $\varepsilon$ of his/her savings in such a way to become strictly better off. The only scenarios satisfying these requirements are (ii) and (iii).

Next suppose that $A$ saves to the point that $B$ is indifferent between going to the bank to reoptimize savings and staying at home at stage $3 \mathrm{~b}$. This strategy must solve the following optimization problem:

$$
\begin{array}{cc}
\max _{s_{1}^{A}, s_{1}^{J}} & u\left(y_{1}-s_{1}^{A}-s_{1}^{J}-b\right)+\delta_{A} u\left(y_{2}+R_{A} s_{1}^{A}+R_{J} s_{1}^{J}-b\right) \quad \text { subject to } \\
u\left(y_{1}-s_{1}^{A}-s_{1}^{J}-b\right)+\delta_{B} u\left(y_{2}+R_{A} s_{1}^{A}+R_{J} s_{1}^{J}-b\right) \geq V_{B}\left(s_{1}^{A}\right) \\
s_{1}^{A} \geq 0, s_{1}^{J} \geq 0
\end{array}
$$

where $V_{B}\left(s_{1}^{A}\right)$ is the utility that agent $B$ would get from paying $b$ and reoptimizing savings at the bank during stage $3 \mathrm{~b} . V_{B}(\cdot)$ depends on $s_{1}^{A}$, since savings in $A$ 's individual account 
cannot be withdrawn by $B$. In contrast, $V_{B}(\cdot)$ does not depend on $s_{1}^{J}$, since $B$ can freely access these funds once she is at the bank.

When $R_{A}>R_{J}$, agent $A$ will only use the individual account for an optimal indifference strategy. To see this, suppose instead that $s_{1}^{J}>0$. Agent $A$ could simply reallocate joint savings to his individual account - first period consumption would stay unchanged, second period consumption would increase, and agent $B$ would strictly prefer to stay at home. Thus, the only remaining strategies involving indifference of $B$ are those listed in (iv).

A key difference between the the simultaneous move game and the sequential move game in the main text is that there may be multiple non-dominated PSPNE that result in distinct consumption allocations. In particular, when $\delta_{A} \neq \delta_{B}$ there may be up to two PSPNE that result in distinct consumption allocations - one that gives spouse $A$ higher utility and one that gives spouse $B$ higher utility. Moreover, note that in the multiple equilibrium case, the PSPNE that gives spouse $i$ the highest utility will correspond to the equilibrium consumption allocation that would prevail in the sequential move game when spouse $i$ is the first mover. Thus, an analog to Proposition 1 in the main text holds, which is that conditional on the discount factor of spouse $-i$, the interest rate loss on spouse $i$ 's most preferred non-dominated PSPNE must increase with monotonic increases in preference heterogeneity.

\section{B Proxying Banking Costs}

I conjecture that those couples who travel to Busia town very frequently for non-bank related reasons and those couples who have low travel costs to town will have smaller differential banking costs (i.e. the joint account offers less in transaction cost savings). This should be negatively correlated with distance from the bank and economic activity (here I assume that subsistence farmers and the unemployed are less likely to take frequent trips to town). Moreover, pre-existing use of a formal savings account should signal lower differential banking costs. Here I include both bank accounts and SACCO accounts as formal accounts.1 To aggregate these measures, I used principal components analysis to extract the first principal component of the data matrix formed by the above-listed variables (results are similar if I convert the measures into standard deviation units and equally weight them). I then normalized this component to construct a "banking costs index", which runs from zero

\footnotetext{
${ }^{1}$ SACCO stands for "savings and credit cooperative". SACCOs function like credit unions, and are generally organized around higher paying professions, such as teaching and commercial farming. There is an argument for excluding the account ownership variables from the index, since this may be determined in part by match quality. In practice, the results are very similar if I exclude the account ownership variables from the banking cost index.
} 
(lowest hypothesized banking costs) to one (highest hypothesized banking costs). Appendix Table B1 checks to see if the cost index is correlated with account behavior in ways predicted by the theory. The first three columns present couple-level regressions of the following form:

$$
y_{c}=\beta_{0}+\beta_{1} \text { index }_{c}+w_{c} \lambda+x_{c}^{\prime} \delta+\varepsilon_{c}
$$

where $y_{c}$ is the outcome of interest, inde $x_{c}$ is the banking cost index, $w_{c}$ includes dummies for husband and wife cash payment selection, each account's free ATM status, and the couple's extra statements status, and $x_{c}$ is a vector of controls. I use the same control sets as in previous regressions, but I exclude controls for occupation (since this is included in the index) as well as village fixed effects (which absorb distance from the bank, which is also included in the index).

It is likely that the cost index is correlated with absolute banking costs and socioeconomic status in addition to differential banking costs. To test the former hypothesis, the first column of Table B1 examines the correlation between the banking cost index and a dummy variable for whether or not a couple saved in any bank account. Indeed, couples with the highest proxied costs are significantly less likely to save in any bank account, which suggests that they have fewer resources and/or face greater costs of using the accounts. The next three columns limit the population to couples who saved in at least one account, and examine the correlation between use of joint versus individual accounts and the cost index. ${ }^{2}$ Higher cost savers are significantly less likely to save individually and more likely to save jointly as compared to lower cost savers. These results are robust to adding observable controls that capture socioeconomic status and other characteristics - though the results examining account use are attenuated upon including economic controls, the coefficients are still large in magnitude and mostly significant.

Earlier, I argued that well matched couples' response to (and poorly matched couples' lack of response to) the excess interest rate suggest that interest rate losses only impacted the decisions of well matched savers with relatively low differential banking costs. I use the proxied banking costs to test this hypothesis directly: in this case well matched couples with low proxied banking costs should respond robustly to the excess interest rate, while well matched couples with large proxied banking costs should be much less responsive to the excess rate. To test this, I limit the sample to well matched couples, define a couple to have

\footnotetext{
${ }^{2}$ In the absence of a selection effect (i.e. conditional on the joint banking cost/savings capacity), larger differential banking costs will push couples to make more intensive use of joint accounts. However, larger absolute banking costs/lower savings capacities will select out smaller scale savers. Since the hypothesized costs are fixed and not proportional to balances, these savers will be more likely to opt for joint accounts, all else equal. Therefore this selection effect would bias me away from finding a positive correlation between joint account use and the cost index.
} 
high banking costs if their index value is above the sample median, and run the following regression:

$$
\begin{aligned}
\text { saved }_{a c}= & \beta_{0}+\beta_{1} \text { high }_{c}+\beta_{2} \text { excess }_{a c}+\beta_{3} \text { high } \\
& x_{c}^{\prime} \alpha+(\text { excess } \times x)_{a c}^{\prime} \zeta+(z \times x)_{a c}^{\prime} \psi+w_{a c}^{\prime} \phi+\varepsilon_{a c}
\end{aligned}
$$

where $h i g h_{c}$ is a dummy variable indicating high banking costs, excess $s_{a c}$ is the excess interest rate on account $a$ for couple $c, z_{a c}$ is a vector including interest rate dummies and a dummy variable identifying joint accounts, and $w_{a c}$ includes dummies for husband and wife cash payment selection, the account's free ATM status, and the couple's extra statements status. Finally, $x_{c}$ is a vector of the same control sets used in the earlier specifications in Appendix Table B1.

The fourth column of Table B1 presents results of this regression. As expected, the response to the excess interest rate is positive and highly significant for couples with lower proxied banking costs and very close to zero for couples with higher proxied banking costs. Overall, these results suggest that the index is a reasonable proxy for differential banking costs, subject to the caveat that it is correlated with other determinants of account use, such as socioeconomic status and absolute banking costs.

\section{Extra Statements Sample and Information Index}

As described in Section II, 50 percent of couples (who attended the seventh experimental session or above) were sampled for an "extra statements" offer. In order to keep selection into individual account opening constant between treatment and control, the experimental protocol dictated that the extra statement offer only be made to participants after they decided which accounts to open. However, extra statement provision is significantly, negatively correlated with the probability of opening an individual account in the overall sample. The enumerators never reported informing couples about the extra statements before account choice, nor did they report any cases where couples changed their minds about opening individual accounts after getting an extra statements offer. However, in a subset of the sessions the enumerators were able to observe couples' extra statements treatment status before couples made account opening choices. The correlation is only significant in this subset of sessions, so I conjecture that some enumerators guided selected couples to joint accounts, as filling out the extra statement cards involved time consuming paperwork. To address this concern, I ran the following regression among all individual accounts in the suspect sessions 
enumerator by enumerator:

$$
\text { open }_{i c}=\beta_{0}+\beta_{1} e s_{c}+\gamma_{e}+\varepsilon_{i c}
$$

Where $i$ indexes the individual, $e s_{c}$ indicates extra statement selection and $\gamma_{e}$ are coenumerator fixed effects (the enumerators worked in teams of two).

Out of 14 enumerators, the coefficient on $e s_{c}$ was negative and significant for just four enumerators. I dropped observations for these four enumerators in the sessions where enumerators could observe extra statement selection prior to the couple's account opening decision. All told, I dropped 344 of 920 individual account observations. Columns 1 and 2 of Appendix Table C1 verify that account opening is uncorrelated with extra statement selection once I drop the suspect enumerators.

Before dropping suspect observations, I created an information sharing index. The index inputs are responses to baseline survey questions addressing income earned last week, bank accounts, savings at home, SACCOs, and ROSCAs, which I use to create five subindices. The subindices range from 0 (perfect information) to 1 (most misinformation). If cross reports exactly matched own reports, I coded the subindex to 0. If an individual reported that they did (did not) use a device, but the spouse reported that they did not (did), I coded the subindex to 1 . If a spouse asserted that they did not know if an individual used a given device, or if they did not know how much savings was in the device, I also coded the subindex to 1. For other instances where I had an own report and a cross report of the amount (or in the case of ROSCAs, the number of ROSCAs), I coded the subindex to equal $\min \left\{\frac{\mid{ }^{\prime} w n_{i c}-\text { cross }_{i c} \mid}{o w n_{i c}}, 1\right\}$. I then created a household-level information index equal to:

$$
\text { index }_{c}^{\text {info }}=1-\frac{1}{2} \sum_{i \in\{M, F\}} \frac{\text { inde } x_{i c}^{i n c}+i n d e x_{i c}^{h h}+i n d e x_{i c}^{\text {bank }}+i n d e x_{i c}^{\text {sacco }}+\text { index }}{\text { rosca }}
$$

where a value of 1 represents a perfectly informed household and a value of 0 represents a poorly informed household.

Appendix Table C1 presents the results of the extra statements intervention. All regressions are of the following form:

$$
y_{a c}=\beta_{0}+\beta_{1} e s_{c}+h t_{c}^{\prime} \lambda+w_{c}^{\prime} \gamma+x_{a c}^{\prime} \delta+\varepsilon_{a c}
$$

where $y_{a c}$ is the outcome of interest, $e s_{c}$ indicates that the couple was selected for (or, in some specifications, consented to) extra statements, $w_{a c}$ controls for the account's interest rate, free ATM status, and husband and wife cash prize selection, and $x_{c}$ is a vector of additional 
controls. To examine treatment effects by preference heterogeneity and household information sharing, in some specifications I also include the vector $h t_{c}$, which includes a dummy for poorly matched couples, a dummy for poorly informed couples, and the interaction of these variables with the extra statements indicator.

The first two columns of Table C1 verify that, as per experimental protocol, the probability of opening an individual account is uncorrelated with extra statement selection. This is in fact the case, and for the remaining specifications I limit the sample to opened individual accounts. The next two specifications examine extra statement consent rates. I find no evidence that poorly informed couples were less likely to consent to the extra statements intervention, though the point estimates on the poorly informed and poorly matched dummies are both negative, as expected.

Columns 5-8 of Table C1 examine the reduced form impact of the extra statements offer on savings rates and average daily balances of open individual accounts. The overall impact of extra statements (columns 5 and 7 ) is relatively small, insignificant, and actually positive in sign. Given the low consent rate, this is not very surprising - individuals who would be most adversely impacted by the extra statements should have been most likely to refuse consent. However, columns 6 and 8 provide some suggestive evidence that poorly matched and poorly informed couples respond more adversely to the extra statements treatment. The extra statements intervention is underpowered, however, so I prefer to interpret these results with caution.

\section{Supplementary Tables and Robustness Checks}

This section describes the supplementary tables and robustness checks in Appendix Tables D1-D12.

Appendix Table D1 Appendix Table D1 verifies that respondents understood and responded to the experimental interest rates. This table displays the results of account level regressions of the following form

$$
y_{a c}=\beta_{0}+\beta_{1} p c t 2_{a c}+\beta_{2} p c t 6_{a c}+\beta_{3} p c t 10_{a c}+\beta_{4} j o i n t_{a c}+w_{a c}^{\prime} \gamma+\varepsilon_{a c}
$$

where $y_{a c}$ is the outcome of interest, $p c t 2_{a c}-p c t 10_{a c}$ are interest rate dummy variables, joint $_{a c}$ identifies joint accounts, and $w_{a c}$ controls for husband and wife cash prize selection, as well as the free ATM and extra statements treatments. 
Appendix Table D2 This table tests whether match quality is correlated with successful long-run follow up, which took place approximately three years after the baseline account opening sessions (column 1), whether couples were truly married at baseline (column 2), and whether couples were still married at the time of long-run follow up (column 3). Note that column 2 limits the sample to successfully followed-up couples, and column three limits the sample to "true" couples whose marital status was re-confirmed during the long-run follow up. All regressions follow the following specification:

$$
y_{c}=\beta_{0}+\beta_{1} \text { badmatch }_{c}+w_{c}^{\prime} \gamma+x_{c}^{\prime} \lambda+\varepsilon_{c}
$$

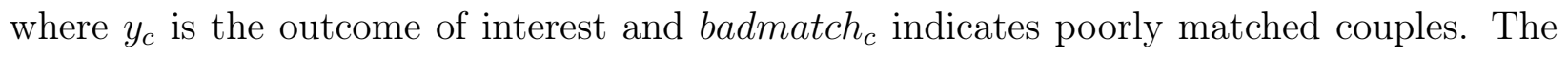
regressions also include a vector of dummy variables for the interest rate on each experimental account, controls for husband and wife cash prize selection, extra statement selection, and the free ATM status of every account $\left(w_{c}\right)$.

Appendix Table D3 Appendix Table D3 presents additional randomization verification results. Panel A tests whether the empirical distributions of treatments differ from their theoretical analogs. This panel displays the share of individuals exposed to each treatment and the p-value from a binomial test that this share is equal to the theoretically expected share. Panel B tests whether treatments are correlated with one another. Each column corresponds to a regression where the treatment of interest is regressed on all other treatments.

Appendix Tables D4-D6 These tables test the robustness of the main results (Tables 4-6) to alternative measures of preference heterogeneity and alternative samples. Table D4 tests the robustness of the results in Table 4, while Tables D5 and D6 test the robustness of the results in Tables 5 and 6 respectively.

In terms of alternative measures of preference heterogeneity, first I present results using alternative rules of thumb for match quality, where I define either $1 / 3$ or $2 / 3$ of couples to be "well matched" based on discount factors. Table D5 also presents results where I use the absolute value of preference heterogeneity, $\left|h e t_{c}\right|$, as a measure of match quality (Panel E).

Next, I estimate discount factors via nonlinear least squares with normally distributed errors (labeled "probit" on the tables), and via an ad hoc bounding strategy similar to that in Meier and Sprenger (2010). Specifically, suppose that for individual $i$, Ksh $X$ at time $t$ is preferred to Ksh 300 at time $t+\tau$, but Ksh 300 at time $t+\tau$ is preferred to $\operatorname{Ksh} Y<X$ at time $t$. I assume that the individual is indifferent between Ksh 300 at time $t+\tau$ and the midpoint of the two amounts $\left(\frac{X+Y}{2}\right)$ at time $t$. I calculate the implied discount factor using this midpoint. I do this for each table of monetary choices, obtaining 10 discount 
factor estimates, and take the simple average of them. Note that I update not just my measure of match quality in these regressions, but also other relevant time preference controls (such as level discount factors, censoring dummies, and decision errors). Since the ad hoc procedure does not produce a measure of decision error I simply use the logit estimates in these specifications.

Finally, these tables include specifications where I (a) drop all couples who were randomly selected to receive at least one cash payment, (b) drop all couples where at least one spouse had censored discount factors, and (c) include polygamous couples. When including polygamist couples I also include a polygamist dummy in the demographic control set.

Appendix Tables D7-D8 These tables replicate the analyses in Tables 4 and 5, but with alternative measures of account use. In particular, I present results using a measure of saving that excludes cash prize deposits (here, "saving" necessitates making at least one deposit other than the cash prize deposit into an account within the 6 month study window), a dummy variable for whether an account was opened, the average balance in both levels and logs, the number of deposits, and the number of transactions. Note that since many accounts have a zero average balance, in the $\log$ specification the dependent variable is $\ln (y+1)$.

Appendix Tables D9-D12 Here I present versions of Table 2, and Tables 4-6 where observations are reweighted to achieve balance on socioeconomic status for the joint excess interest rate. To construct the weights I run couple-level probit regressions of the following form:

$$
e x_{-} k_{c}=\beta_{0}+\sum_{j=1}^{11} \beta_{j} x_{c}^{j}+\varepsilon_{c}
$$

where $e x \_k_{c}$ is a dummy equal to one if the excess interest rate on couple $c$ 's joint account is equal to $k$, and $x_{c}^{j}$ is demographic characteristic $j$ for couple $c$. The included characteristics include both husbands' and wives' education, literacy, number of children, a subsistence farmer/unemployed dummy, and distance from the bank. I then calculate each couples predicted probability of receiving excess interest rate $k$ based on their demographic characteristics and construct the weights so that once weighted, each couple has a probability of receiving excess interest rate $k$ equal to the true theoretical probability generated by the interest rate design. 


\section{References}

Meier, S. and C. Sprenger (2010). Present-Biased Preferences and Credit Card Borrowing. American Economic Journal: Applied Economics 2(1), 193-210. 
Appendix Table B1. Proxied Banking Costs and Savings Behavior

\begin{tabular}{|c|c|c|c|c|}
\hline & \multicolumn{3}{|c|}{ Couple Level } & \multirow{2}{*}{$\frac{\text { Account Level }}{\text { Saved }}$} \\
\hline & Saved Any & Saved Indiv. & Saved Joint & \\
\hline \multicolumn{5}{|l|}{ Panel A. Basic Controls } \\
\hline Cost Index/High Cost & $\begin{array}{c}-0.397 * * * \\
(0.116)\end{array}$ & $\begin{array}{c}-0.895^{* * *} \\
(0.168)\end{array}$ & $\begin{array}{c}0.625 * * * \\
(0.176)\end{array}$ & $\begin{array}{c}-0.173 * * * \\
(0.061)\end{array}$ \\
\hline Excess & & & & $\begin{array}{c}0.015 * * * \\
(0.006)\end{array}$ \\
\hline Excess $\times$ High Cost & & & & $\begin{array}{c}-0.015^{* *} \\
(0.007)\end{array}$ \\
\hline \multicolumn{5}{|c|}{ Panel B. + Time Preference Controls } \\
\hline Cost Index/High Cost & $\begin{array}{c}-0.383 * * * \\
(0.118)\end{array}$ & $\begin{array}{c}-0.920 * * * \\
(0.178)\end{array}$ & $\begin{array}{c}0.636^{* * *} \\
(0.180)\end{array}$ & $\begin{array}{c}-0.195 * * * \\
(0.066)\end{array}$ \\
\hline Excess & & & & $\begin{array}{c}0.016^{* * * *} \\
(0.006)\end{array}$ \\
\hline Excess $\times$ High Cost & & & & $\begin{array}{c}-0.017 * * \\
(0.007)\end{array}$ \\
\hline \multicolumn{5}{|c|}{ Panel C. + Demographic Controls } \\
\hline Cost Index/High Cost & $\begin{array}{c}-0.304 * * * \\
(0.126)\end{array}$ & $\begin{array}{c}-1.08 * * * \\
(0.190)\end{array}$ & $\begin{array}{c}0.710 * * * \\
(0.202)\end{array}$ & $\begin{array}{c}-0.181 * * * \\
(0.074)\end{array}$ \\
\hline Excess & & & & $\begin{array}{c}0.021 * * * \\
(0.006)\end{array}$ \\
\hline Excess $\times$ High Cost & & & & $\begin{array}{l}-0.017^{*} \\
(0.009)\end{array}$ \\
\hline \multicolumn{5}{|c|}{ Panel D. + Economic and Decision Making Controls } \\
\hline Cost Index/High Cost & $\begin{array}{c}-0.354 * * * \\
(0.146)\end{array}$ & $\begin{array}{c}-1.05 * * * \\
(0.239)\end{array}$ & $\begin{array}{c}0.602 * * * \\
(0.247)\end{array}$ & $\begin{array}{c}-0.219^{* *} \\
(0.099)\end{array}$ \\
\hline Excess & & & & $\begin{array}{c}0.021 * * \\
(0.010)\end{array}$ \\
\hline Excess $\times$ High Cost & & & & $\begin{array}{l}-0.022 * \\
(0.011)\end{array}$ \\
\hline DV Mean & & & & 0.163 \\
\hline $\mathrm{N}$ & 544 & 237 & 237 & 816 \\
\hline Sample & All & Savers & Savers & Well Matched \\
\hline
\end{tabular}

Notes: Robust standard errors (clustered at the couple level when relevant) in parentheses. I proxy banking costs by extracting the first principal component of distance from the bank, spouse-specific indicators for subsistence farmers/the unemployed, and spouse-specific indicators for baseline bank account ownership and SACCO membership. This index is re-normalized to range from 0 (lowest proxied costs) to 1 (highest proxied costs). The first three columns use the cost index as a covariate, while the last column uses the high cost dummy. See notes to Table 4 for the basic (couple-level regressions only), time preference, and decision making control sets. Basic controls in the account-level specification include a dummy identifying joint accounts, dummies for the account's interest rate, and dummies for free ATM selection, extra statements selection, and husband and wife cash payment selection. The demographic control set includes spousal heterogeneity in age, education, number of children, and literacy. The economic control set adds controls for heterogeneity in income and mobile phone ownership. In the account level specification the high cost dummy as well as all time preference, demographic, economic, and decision making controls are interacted with the excess interest rate, the interest rate dummies, and the joint account indicator. All these variables except the high cost dummy are demeaned before constructing interaction terms. ${ }^{* * *}, * *$, and $*$ indicate significance at the 99,95 , and 90 percent confidence levels respectively. 
Appendix Table C1. Impact of Extra Statements on Savings and Average Balances of Individual Accounts

\begin{tabular}{|c|c|c|c|c|c|c|c|c|}
\hline & \multirow{2}{*}{\multicolumn{2}{|c|}{$\begin{array}{c}\text { Protocol Check } \\
\text { Opened } \\
\end{array}$}} & \multirow{2}{*}{\multicolumn{2}{|c|}{$\begin{array}{c}\text { First Stage } \\
\text { Consented to ES }\end{array}$}} & \multicolumn{4}{|c|}{ Reduced Forms } \\
\hline \multirow{3}{*}{ Panel A. Basic Controls } & & & & & \multicolumn{2}{|c|}{ Saved } & \multicolumn{2}{|c|}{ Average Balance } \\
\hline & \multicolumn{2}{|c|}{ (1) (2) } & \multicolumn{2}{|c|}{$(3) \quad(4)$} & $(5)$ & (6) & $(7)$ & $(8)$ \\
\hline & \\
\hline Extra Statement & $\begin{array}{l}-0.043 \\
(0.053)\end{array}$ & $\begin{array}{c}0.072 \\
(0.085)\end{array}$ & $\begin{array}{c}0.695 * * * \\
(0.068)\end{array}$ & $\begin{array}{c}0.822 * * * \\
(0.119)\end{array}$ & $\begin{array}{c}0.057 \\
(0.064)\end{array}$ & $\begin{array}{c}0.142 \\
(0.135)\end{array}$ & $\begin{array}{c}324 \\
(217)\end{array}$ & $\begin{array}{c}617 \\
(541)\end{array}$ \\
\hline x Poorly Matched & & $\begin{array}{l}-0.100 \\
(0.105)\end{array}$ & & $\begin{array}{l}-0.104 \\
(0.147)\end{array}$ & & $\begin{array}{l}-0.163 \\
(0.131)\end{array}$ & & $\begin{array}{l}-307 \\
(391)\end{array}$ \\
\hline x Poorly Informed & & $\begin{array}{l}-0.095 \\
(0.113)\end{array}$ & & $\begin{array}{l}-0.140 \\
(0.154)\end{array}$ & & $\begin{array}{l}-0.042 \\
(0.141)\end{array}$ & & $\begin{array}{l}-163 \\
(468)\end{array}$ \\
\hline \multicolumn{9}{|c|}{ Panel B. + Time Preference Controls } \\
\hline Extra Statement & $\begin{array}{l}-0.053 \\
(0.055)\end{array}$ & $\begin{array}{c}0.064 \\
(0.089)\end{array}$ & $\begin{array}{c}0.681 * * * \\
(0.066)\end{array}$ & $\begin{array}{c}0.804 * * * \\
(0.126)\end{array}$ & $\begin{array}{c}0.035 \\
(0.062)\end{array}$ & $\begin{array}{c}0.102 \\
(0.133)\end{array}$ & $\begin{array}{c}333 \\
(214)\end{array}$ & $\begin{array}{c}725 \\
(583)\end{array}$ \\
\hline x Poorly Matched & & $\begin{array}{l}-0.115 \\
(0.108)\end{array}$ & & $\begin{array}{l}-0.148 \\
(0.160)\end{array}$ & & $\begin{array}{l}-0.147 \\
(0.148)\end{array}$ & & $\begin{array}{l}-127 \\
(456)\end{array}$ \\
\hline x Poorly Informed & & $\begin{array}{l}-0.082 \\
(0.115)\end{array}$ & & $\begin{array}{l}-0.105 \\
(0.167)\end{array}$ & & $\begin{array}{l}-0.056 \\
(0.144)\end{array}$ & & $\begin{array}{l}-434 \\
(556)\end{array}$ \\
\hline \multicolumn{9}{|c|}{ Panel C. + Demographic Controls } \\
\hline Extra Statement & $\begin{array}{l}-0.049 \\
(0.055)\end{array}$ & $\begin{array}{l}-0.028 \\
(0.099)\end{array}$ & $\begin{array}{c}0.654 * * * \\
(0.073)\end{array}$ & $\begin{array}{c}0.819 * * * \\
(0.139)\end{array}$ & $\begin{array}{l}-0.010 \\
(0.062)\end{array}$ & $\begin{array}{c}0.131 \\
(0.117)\end{array}$ & $\begin{array}{c}122 \\
(144)\end{array}$ & $\begin{array}{l}733 * * \\
(317)\end{array}$ \\
\hline x Poorly Matched & & $\begin{array}{l}-0.020 \\
(0.109)\end{array}$ & & $\begin{array}{l}-0.230 \\
(0.153)\end{array}$ & & $\begin{array}{l}-0.254^{*} \\
(0.138)\end{array}$ & & $\begin{array}{l}22.9 \\
(331)\end{array}$ \\
\hline x Poorly Informed & & $\begin{array}{l}-0.001 \\
(0.124)\end{array}$ & & $\begin{array}{l}-0.067 \\
(0.156)\end{array}$ & & $\begin{array}{l}-0.202^{*} \\
(0.120)\end{array}$ & & $\begin{array}{c}-900 * * * \\
(359)\end{array}$ \\
\hline \multicolumn{9}{|c|}{ Panel D. + Economic and Decision Making Controls } \\
\hline Extra Statement & $\begin{array}{l}-0.038 \\
(0.056)\end{array}$ & $\begin{array}{l}-0.062 \\
(0.105)\end{array}$ & $\begin{array}{c}0.666 * * * \\
(0.080)\end{array}$ & $\begin{array}{c}0.784 * * * \\
(0.142)\end{array}$ & $\begin{array}{l}-0.081 \\
(0.061)\end{array}$ & $\begin{array}{l}-0.088 \\
(0.140)\end{array}$ & $\begin{array}{c}23.2 \\
(155)\end{array}$ & $\begin{array}{l}555^{*} \\
(311)\end{array}$ \\
\hline x Poorly Matched & & $\begin{array}{l}-0.013 \\
(0.114)\end{array}$ & & $\begin{array}{l}-0.195 \\
(0.147)\end{array}$ & & $\begin{array}{l}-0.215 \\
(0.159)\end{array}$ & & $\begin{array}{l}-74.7 \\
(406)\end{array}$ \\
\hline x Poorly Informed & & $\begin{array}{c}0.032 \\
(0.130)\end{array}$ & & $\begin{array}{l}-0.096 \\
(0.167)\end{array}$ & & $\begin{array}{l}-0.062 \\
(0.140)\end{array}$ & & $\begin{array}{c}-732 * * \\
(368)\end{array}$ \\
\hline DV Mean $(E S=0)$ & \multicolumn{2}{|c|}{0.383} & & \multicolumn{2}{|c|}{0.268} & \multicolumn{2}{|c|}{236} \\
\hline $\mathrm{N}$ & \multicolumn{2}{|c|}{576} & \multicolumn{2}{|c|}{210} & \multicolumn{2}{|c|}{210} & \multicolumn{2}{|c|}{210} \\
\hline Sample & \multicolumn{2}{|c|}{ All Accts. } & \multicolumn{2}{|c|}{ Open Accts. } & Ope & cets. & Op & cets. \\
\hline
\end{tabular}

Notes: Robust standard errors clustered at the couple level in parentheses. All regressions except for columns 1 and 2 are limited to open individual accounts. Basic controls include a dummy identifying joint accounts, dummies for the account's interest rate, and dummies for free ATM selection, extra statements selection, and husband and wife cash payment selection. See notes to Table 4 for the time preference, demographic, economic, and decision making control sets. $* * * * *$, and * indicate significance at the 99,95 , and 90 percent confidence levels respectively. 


\begin{tabular}{|c|c|c|c|c|c|}
\hline & Opened & Saved & $\begin{array}{l}\text { Number } \\
\text { Deposits }\end{array}$ & $\begin{array}{l}\text { Average } \\
\text { Balance }\end{array}$ & $\begin{array}{l}\text { Average } \\
\text { Balance } \\
(\log +1)\end{array}$ \\
\hline \multicolumn{6}{|c|}{ Panel A. All Accounts Offered to All Couples } \\
\hline $2 \%$ Interest & $\begin{array}{c}0.049 \\
(0.035)\end{array}$ & $\begin{array}{c}0.013 \\
(0.021)\end{array}$ & $\begin{array}{c}0.046 \\
(0.080)\end{array}$ & $\begin{array}{c}8.77 \\
(41.2)\end{array}$ & $\begin{array}{c}0.040 \\
(0.122)\end{array}$ \\
\hline $6 \%$ Interest & $\begin{array}{c}0.141 * * * \\
(0.037)\end{array}$ & $\begin{array}{c}0.076^{* * *} \\
(0.022)\end{array}$ & $\begin{array}{c}0.083 \\
(0.073)\end{array}$ & $\begin{array}{c}73.3 \\
(55.7)\end{array}$ & $\begin{array}{c}0.394 * * * \\
(0.132)\end{array}$ \\
\hline $10 \%$ Interest & $\begin{array}{c}0.197 * * * \\
(0.038)\end{array}$ & $\begin{array}{c}0.093 * * * \\
(0.023)\end{array}$ & $\begin{array}{c}0.362 * * * \\
(0.104)\end{array}$ & $\begin{array}{l}127 * * \\
(55.9)\end{array}$ & $\begin{array}{c}0.538 * * * \\
(0.139)\end{array}$ \\
\hline Joint & $\begin{array}{c}0.314 * * * \\
(0.038)\end{array}$ & $\begin{array}{c}0.211 * * * \\
(0.025)\end{array}$ & $\begin{array}{c}0.474 * * * \\
(0.102)\end{array}$ & $\begin{array}{c}134 * * * \\
(51.0)\end{array}$ & $\begin{array}{l}1.16^{* * *} \\
(0.145)\end{array}$ \\
\hline DV Mean (Omitted) & 0.269 & 0.044 & 0.114 & 50.6 & 0.267 \\
\hline $\mathrm{N}$ & 1632 & 1632 & 1632 & 1632 & 1632 \\
\hline \multicolumn{6}{|c|}{ Panel B. All Accounts Offered to Well Matched Couples } \\
\hline $2 \%$ Interest & $\begin{array}{c}0.017 \\
(0.048)\end{array}$ & $\begin{array}{l}0.013 \\
(0.027)\end{array}$ & $\begin{array}{c}0.025 \\
(0.110)\end{array}$ & $\begin{array}{c}20.3 \\
(40.7)\end{array}$ & $\begin{array}{l}-0.024 \\
(0.150)\end{array}$ \\
\hline $6 \%$ Interest & $\begin{array}{c}0.124 * * * \\
(0.053)\end{array}$ & $\begin{array}{c}0.065^{* * *} \\
(0.028)\end{array}$ & $\begin{array}{c}0.024 \\
(0.089)\end{array}$ & $\begin{array}{c}109 \\
(81.2)\end{array}$ & $\begin{array}{c}0.382 * * \\
(0.164)\end{array}$ \\
\hline $10 \%$ Interest & $\begin{array}{c}0.235 * * * \\
(0.053)\end{array}$ & $\begin{array}{c}0.115 * * * \\
(0.031)\end{array}$ & $\begin{array}{c}0.342 * * * \\
(0.134)\end{array}$ & $\begin{array}{c}190 * * * \\
(72.2)\end{array}$ & $\begin{array}{c}0.633 * * * \\
(0.196)\end{array}$ \\
\hline Joint & $\begin{array}{c}0.310 * * * \\
(0.054)\end{array}$ & $\begin{array}{c}0.235 * * * \\
(0.035)\end{array}$ & $\begin{array}{c}0.484 * * * \\
(0.119)\end{array}$ & $\begin{array}{c}107 \\
(78.2)\end{array}$ & $\begin{array}{l}1.30^{* * * *} \\
(0.199)\end{array}$ \\
\hline DV Mean (Omitted) & 0.281 & 0.022 & 0.079 & 15.6 & 0.137 \\
\hline $\mathrm{N}$ & 816 & 816 & 816 & 816 & 816 \\
\hline \multicolumn{6}{|c|}{ Panel C. All Accounts Offered to Poorly Matched Couples } \\
\hline $2 \%$ Interest & $\begin{array}{c}0.074 \\
(0.052)\end{array}$ & $\begin{array}{l}0.008 \\
(0.034)\end{array}$ & $\begin{array}{c}0.052 \\
(0.116)\end{array}$ & $\begin{array}{l}-16.2 \\
(70.9)\end{array}$ & $\begin{array}{c}0.064 \\
(0.196)\end{array}$ \\
\hline $6 \%$ Interest & $\begin{array}{c}0.156^{* * *} \\
(0.051)\end{array}$ & $\begin{array}{c}0.079 * * * \\
(0.034)\end{array}$ & $\begin{array}{c}0.122 \\
(0.121)\end{array}$ & $\begin{array}{l}17.0 \\
(74.2)\end{array}$ & $\begin{array}{l}0.342^{*} \\
(0.206)\end{array}$ \\
\hline $10 \%$ Interest & $\begin{array}{c}0.156^{* * *} \\
(0.054)\end{array}$ & $\begin{array}{c}0.069 * * \\
(0.032)\end{array}$ & $\begin{array}{c}0.372 * * * \\
(0.159)\end{array}$ & $\begin{array}{c}57.1 \\
(86.6)\end{array}$ & $\begin{array}{l}0.423 * * \\
(0.196)\end{array}$ \\
\hline Joint & $\begin{array}{c}0.319 * * * \\
(0.054)\end{array}$ & $\begin{array}{c}0.190 * * * \\
(0.036)\end{array}$ & $\begin{array}{c}0.476^{* * *} \\
(0.167)\end{array}$ & $\begin{array}{c}173 * * * \\
(69.2)\end{array}$ & $\begin{array}{l}1.04 * * * \\
(0.212)\end{array}$ \\
\hline $\begin{array}{l}\text { DV Mean (Omitted) } \\
\text { N }\end{array}$ & $\begin{array}{c}0.258 \\
816\end{array}$ & $\begin{array}{c}0.068 \\
816\end{array}$ & $\begin{array}{c}0.152 \\
816\end{array}$ & $\begin{array}{l}87.4 \\
816\end{array}$ & $\begin{array}{c}0.404 \\
816\end{array}$ \\
\hline
\end{tabular}

Notes: Omitted group is individual accounts, zero percent interest. Robust standard errors clustered at the couple level in parentheses. All regressions include separate dummies for husband and wife cash payment, extra statement, and free ATM selection. ***,**, and * indicate significance at the 99,95 , and 90 percent confidence levels respectively. 


\section{Appendix Table D2. Follow-Up and Marital Status by Match Quality}

\begin{tabular}{|c|c|c|c|}
\hline Outcome: & $\begin{array}{l}\text { Has follow } \\
\text { up }\end{array}$ & $\begin{array}{l}\text { "True" } \\
\text { couple }\end{array}$ & $\begin{array}{l}\text { Married at } \\
\text { follow-up }\end{array}$ \\
\hline \multicolumn{4}{|l|}{ Panel A. No Controls } \\
\hline Poorly Matched & $\begin{array}{l}-0.020 \\
(0.015)\end{array}$ & $\begin{array}{c}-0.042 * * \\
(0.019)\end{array}$ & $\begin{array}{l}-0.033 \\
(0.025)\end{array}$ \\
\hline \multicolumn{4}{|l|}{ Panel B. + Basic Controls } \\
\hline Poorly Matched & $\begin{array}{l}-0.021 \\
(0.016)\end{array}$ & $\begin{array}{c}-0.043 * * \\
(0.019)\end{array}$ & $\begin{array}{l}-0.039 \\
(0.026)\end{array}$ \\
\hline \multicolumn{4}{|c|}{ Panel C. + Time Preference Controls } \\
\hline Poorly Matched & $\begin{array}{l}-0.021 \\
(0.021)\end{array}$ & $\begin{array}{c}-0.063 * * * \\
(0.023)\end{array}$ & $\begin{array}{c}-0.065^{* *} \\
(0.032)\end{array}$ \\
\hline \multicolumn{4}{|c|}{ Panel D. +Demographic Controls } \\
\hline Poorly Matched & $\begin{array}{l}-0.025 \\
(0.022)\end{array}$ & $\begin{array}{c}-0.076^{* * *} \\
(0.022)\end{array}$ & $\begin{array}{c}-0.072 * * \\
(0.032)\end{array}$ \\
\hline \multicolumn{4}{|l|}{ Panel E. +Economic Controls } \\
\hline Poorly Matched & $\begin{array}{c}-0.024 \\
(0.022)\end{array}$ & $\begin{array}{c}-0.079 * * * \\
(0.024)\end{array}$ & $\begin{array}{c}-0.074 * * \\
(0.032)\end{array}$ \\
\hline \multicolumn{4}{|c|}{ Panel F. +Decision Making Controls } \\
\hline Poorly Matched & $\begin{array}{c}-0.031 \\
(0.022)\end{array}$ & $\begin{array}{c}-0.070 * * * \\
(0.024)\end{array}$ & $\begin{array}{c}-0.089 * * * \\
(0.032)\end{array}$ \\
\hline DV Mean (Well Matched) & 0.973 & 0.965 & 0.919 \\
\hline $\mathrm{N}$ & 598 & 576 & 544 \\
\hline Sample: & $\begin{array}{c}\text { Baseline } \\
\text { sample }\end{array}$ & $\begin{array}{l}\text { Couples with } \\
\text { follow-up }\end{array}$ & "True" couples \\
\hline
\end{tabular}

Notes: Heteroskedasticity robust standard errors in parentheses. A couple is classified as poorly matched if they score above median in terms of discount factor heterogeneity. This classification is recomputed each time the sample changes. See notes to Table 4 for basic, time preference, demographic, and economic controls. $* * *, * *$, and $*$ indicate significance at the 99,95 , and 90 percent confidence levels respectively. 
Appendix Table D3. Additional Randomization Verification

\begin{tabular}{lccccc}
\hline \hline Panel A. Do Realized Treatment Proportions Differ & From Theoretical Treatment Proportions? & \\
& \multicolumn{2}{c}{ Level Interest Rate on: } & & \\
\cline { 2 - 4 } & Husband's & Wife's & Joint & Extra & Cash \\
& Account & Account & Account & Statements & Payment \\
\hline 10\% Interest/Extra Stmts/Cash & 0.232 & 0.237 & 0.325 & $0.450^{* *}$ & $0.177^{*}$ \\
& $\{0.347\}$ & $\{0.520\}$ & $\{0.716\}$ & $\{0.036\}$ & $\{0.063\}$ \\
6\% Interest Rate & 0.250 & 0.261 & 0.349 & & \\
& $\{1.00\}$ & $\{0.553\}$ & $\{0.440\}$ & \\
2\% Interest Rate & 0.254 & 0.268 & 0.325 & \\
& $0.843\}$ & $\{0.322\}$ & $\{0.716\}$ & \\
0\% Interest Rate & 0.265 & 0.233 & & & \\
& $00.428\}$ & $\{0.400\}$ & & &
\end{tabular}

Panel B. Are Treatments Correlated With One Another?

\begin{tabular}{lccccc} 
& \multicolumn{2}{c}{ Excess Interest Rate on: } & & \\
\cline { 2 - 5 } & $\begin{array}{c}\text { Husband's } \\
\text { Account }\end{array}$ & $\begin{array}{c}\text { Wife's } \\
\text { Account }\end{array}$ & $\begin{array}{c}\text { Joint } \\
\text { Account }\end{array}$ & $\begin{array}{c}\text { Extra } \\
\text { Statements }\end{array}$ & $\begin{array}{c}\text { Cash } \\
\text { Payment }\end{array}$ \\
\hline Excess Interest - Husband's Account & & $-0.737^{* * *}$ & $-0.711^{* * *}$ & 0.000 & 0.004 \\
& & $(0.025)$ & $(0.023)$ & $(0.008)$ & $(0.004)$ \\
Excess Interest - Wife's Account & $-0.805^{* * *}$ & & $-0.759^{* * *}$ & -0.001 & 0.004 \\
& $(0.027)$ & & $(0.022)$ & $(0.009)$ & $(0.004)$ \\
Excess Interest - Joint Account & $-0.920^{* * *}$ & $-0.899^{* * *}$ & & 0.003 & 0.006 \\
& $(0.022)$ & $(0.020)$ & & $(0.009)$ & $(0.005)$ \\
Extra Statements & 0.011 & -0.036 & 0.066 & & -0.010 \\
& $(0.260)$ & $(0.248)$ & $(0.230)$ & & $(0.024)$ \\
Cash Payment & 0.182 & 0.165 & 0.241 & -0.017 & \\
N & $(0.207)$ & $(0.201)$ & $(0.180)$ & $(0.041)$ & \\
\hline
\end{tabular}

Notes: Panel A shows the proportion of the sample selected for each treatment, as well as p-values (in braces) from binomial tests that the realized proportion is equal to the theoretical proportion.

Theoretical probabilities are $1 / 4$ for the first two columns, $1 / 3$ for the third column, $1 / 2$ for the fourth column, and $1 / 5$ for the final column.

Each column in Panel B presents results of regressing the treatment of interest (column heading) on the remaining treatments. Regressions in columns 1-4 include an additional dummy variable for couples who were not eligible for the extra statements treatment. Standard errors clustered at the couple level are in parentheses.

$* * *, * *$, and $*$ indicate significance at the 99,95 , and 90 percent confidence levels respectively. 
Appendix Table D4. Robustness Checks - Preference Heterogeneity and Account Use

\begin{tabular}{|c|c|c|}
\hline & \multicolumn{2}{|c|}{ Couples with Dominated Individual Account } \\
\hline & All & Savers \\
\hline \multicolumn{3}{|c|}{ Panel A. Logit NLLS, Well Matched - 33\% } \\
\hline \multirow[t]{2}{*}{ Poorly Matched } & $0.174 * * *$ & $0.400 * * *$ \\
\hline & $(0.044)$ & $(0.162)$ \\
\hline DV Mean (Well Matched) & 0.045 & 0.104 \\
\hline $\mathrm{N}$ & 331 & 147 \\
\hline \multicolumn{3}{|c|}{ Panel B. Logit NLLS, Well Matched - 67\% } \\
\hline \multirow[t]{2}{*}{ Poorly Matched } & $0.124 * *$ & 0.217 \\
\hline & $(0.057)$ & $(0.177)$ \\
\hline DV Mean (Well Matched) & 0.088 & 0.204 \\
\hline $\mathrm{N}$ & 331 & 147 \\
\hline \multicolumn{3}{|c|}{ Panel C.Probit NLLS, Well Matched - 50\% } \\
\hline \multirow[t]{2}{*}{ Poorly Matched } & $0.145 * * *$ & 0.273 \\
\hline & $(0.054)$ & $(0.173)$ \\
\hline DV Mean (Well Matched) & 0.080 & 0.188 \\
\hline $\mathrm{N}$ & 331 & 147 \\
\hline \multicolumn{3}{|c|}{ Panel D. Ad Hoc Discount Factors, Well Matched - 50\% } \\
\hline \multirow[t]{2}{*}{ Absolute Value of Heterogeneity } & $0.117 * * *$ & 0.194 \\
\hline & $(0.045)$ & $(0.131)$ \\
\hline DV Mean (Well Matched) & 0.085 & 0.192 \\
\hline $\mathrm{N}$ & 331 & 147 \\
\hline \multicolumn{3}{|c|}{ Panel E. Absolute Value Preference Heterogeneity } \\
\hline \multirow[t]{2}{*}{ Poorly Matched } & $0.230 * * *$ & $0.469 * *$ \\
\hline & $(0.075)$ & $(0.235)$ \\
\hline DV Mean (All) & 0.124 & 0.279 \\
\hline $\mathrm{N}$ & 331 & 147 \\
\hline \multicolumn{3}{|l|}{ Panel F. Drop Cash Payment Recipients } \\
\hline \multirow[t]{2}{*}{ Poorly Matched } & 0.054 & 0.337 \\
\hline & $(0.038)$ & $(0.281)$ \\
\hline DV Mean (Well Matched) & 0.039 & 0.182 \\
\hline $\mathrm{N}$ & 213 & 51 \\
\hline \multicolumn{3}{|c|}{ Panel G. Drop Couples with Censored Discount Factors } \\
\hline \multirow[t]{2}{*}{ Poorly Matched } & 0.067 & 0.081 \\
\hline & $(0.058)$ & $(0.161)$ \\
\hline DV Mean (Well Matched) & 0.068 & 0.138 \\
\hline $\mathrm{N}$ & 121 & 56 \\
\hline \multicolumn{3}{|l|}{ Panel H. Include Polygamous Couples } \\
\hline \multirow[t]{2}{*}{ Poorly Matched } & $0.107 * * *$ & 0.122 \\
\hline & $(0.039)$ & $(0.120)$ \\
\hline DV Mean (Well Matched) & 0.126 & 0.269 \\
\hline $\mathrm{N}$ & 438 & 204 \\
\hline
\end{tabular}

Notes: Heteroskedasticity robust standard errors in parentheses. The sample is limited to the subset of couples for whom the joint account bears the highest interest rate. The dependent variable is a dummy indicating that a couple saved in any individual account. All regressions include basic, time preference, demographic, economic, and decision making controls sets (as decribed by Table 4) except Panels F and G. These panels only include up to the time preference control set because the small sample size cannot support larger control sets in the "savers only" specification. ***, **, and * indicate significance at the 99,95 , and 90 percent confidence levels respectively. 
Appendix Table D5. Robustness Checks - Responses to the Excess Interest Rate by Match Quality

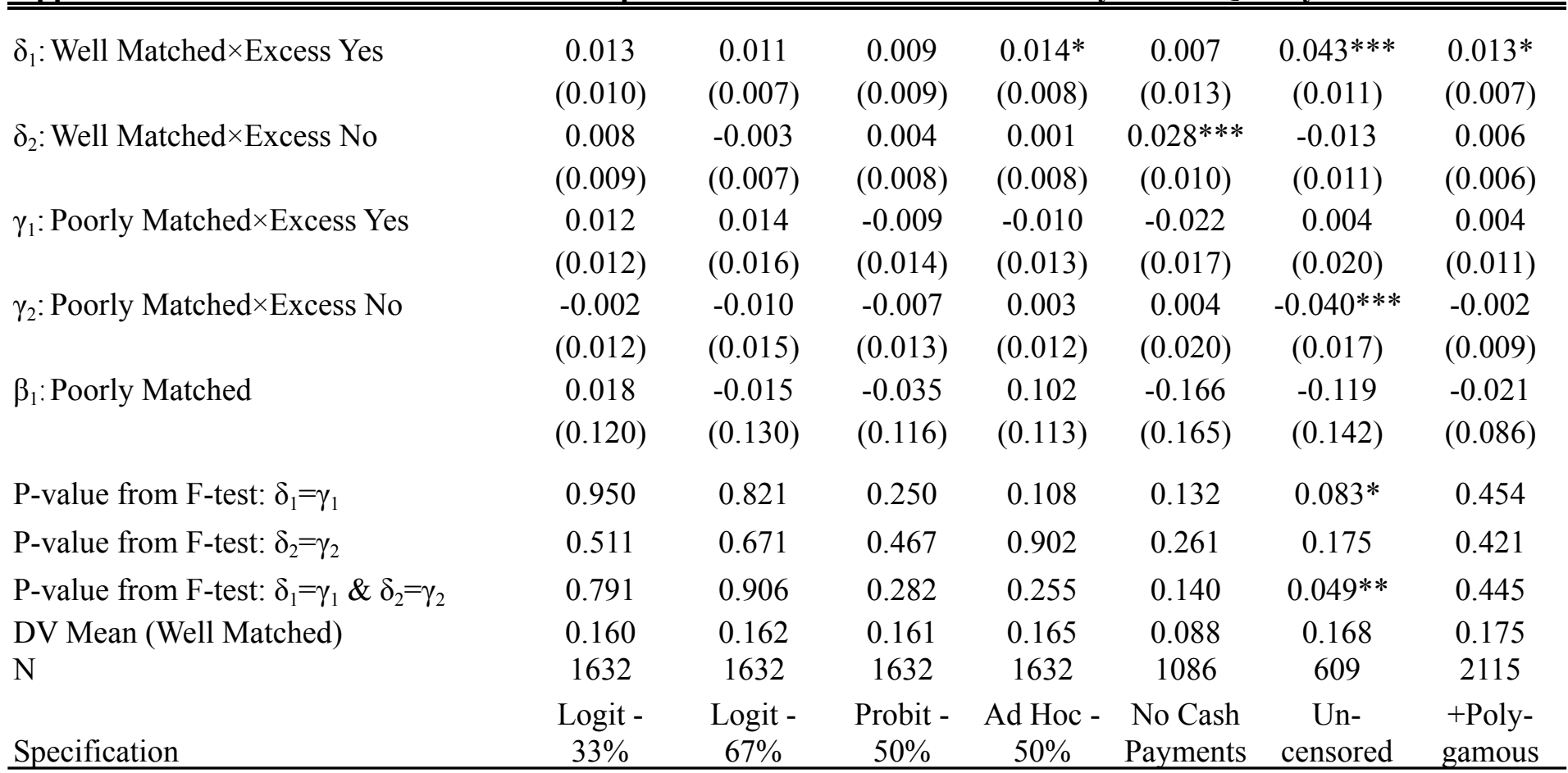

Notes: Data is at the account level. The dependent variable is a dummy indicating that an account received a savings deposit. Robust standard errors clustered at the couple level in parentheses. All specifications include the basic, the time preference, demographic, economic, and decision making control sets (as well as relevant interactions) described in Table 5. In the final column, a dummy variable identifying polygamous couples is included in the demographic control set. ***, $* *$, and * indicate significance at the 99,95 , and 90 percent confidence levels respectively. 


\begin{tabular}{|c|c|c|c|c|c|c|c|}
\hline & Logit 33\% & Logit $67 \%$ & Probit $50 \%$ & Ad Hoc $50 \%$ & $\begin{array}{c}\text { No Cash } \\
\text { Payment } \\
\text { Recipients } \\
\end{array}$ & $\begin{array}{c}\text { Uncensored } \\
\text { Couples } \\
\text { Only } \\
\end{array}$ & $\begin{array}{c}\text { Include } \\
\text { Polygamists }\end{array}$ \\
\hline \multicolumn{8}{|l|}{ Poorly Matched Couples } \\
\hline Maximum Interest Earnings & 8.07 & 8.24 & 8.21 & 8.13 & 8.10 & 8.27 & 8.22 \\
\hline Actual Interest Earnings & 7.06 & 7.16 & 7.14 & 7.10 & 7.09 & 7.17 & 7.13 \\
\hline Loss & 1.05 & 1.06 & 1.07 & 1.06 & 1.11 & 0.974 & 1.09 \\
\hline \multicolumn{8}{|l|}{ Well Matched Couples } \\
\hline Maximum Interest Earnings & 8.34 & 8.12 & 8.12 & 8.19 & 8.10 & 8.34 & 8.13 \\
\hline Actual Interest Earnings & 7.46 & 7.25 & 7.30 & 7.34 & 7.18 & 7.21 & 7.38 \\
\hline Loss & 0.824 & 0.895 & 0.852 & 0.861 & 1.02 & 0.946 & 0.746 \\
\hline \multicolumn{8}{|l|}{ Loss Gap } \\
\hline A. No Controls & $\begin{array}{c}0.474 * * * \\
(0.166)\end{array}$ & $\begin{array}{c}0.208 \\
(0.195)\end{array}$ & $\begin{array}{c}0.350^{* *} \\
(0.178)\end{array}$ & $\begin{array}{c}0.320^{*} \\
(0.178)\end{array}$ & $\begin{array}{c}0.273 \\
(0.176)\end{array}$ & $\begin{array}{c}0.170 \\
(0.278)\end{array}$ & $\begin{array}{c}0.346^{* *} \\
(0.162)\end{array}$ \\
\hline B. + Basic Controls & $\begin{array}{c}0.500^{* * *} \\
(0.161)\end{array}$ & $\begin{array}{c}0.275 \\
(0.186)\end{array}$ & $\begin{array}{c}0.418^{* * *} \\
(0.167)\end{array}$ & $\begin{array}{c}0.438^{* * *} \\
(0.169)\end{array}$ & $\begin{array}{l}0.284^{*} \\
(0.165)\end{array}$ & $\begin{array}{c}0.107 \\
(0.260)\end{array}$ & $\begin{array}{c}0.418^{* * *} \\
(0.157)\end{array}$ \\
\hline C. + Time Preference Controls & $\begin{array}{c}0.615 * * * \\
(0.192)\end{array}$ & $\begin{array}{c}0.085 \\
(0.249)\end{array}$ & $\begin{array}{l}0.411^{*} \\
(0.226)\end{array}$ & $\begin{array}{c}0.418^{* *} \\
(0.202)\end{array}$ & $\begin{array}{c}0.175 \\
(0.290)\end{array}$ & $\begin{array}{c}0.545 \\
(0.351)\end{array}$ & $\begin{array}{c}0.466^{* * * *} \\
(0.192)\end{array}$ \\
\hline D. + Demographic Controls & $\begin{array}{c}0.608 * * * \\
(0.192)\end{array}$ & $\begin{array}{c}0.117 \\
(0.254)\end{array}$ & $\begin{array}{c}0.472 * * \\
(0.228)\end{array}$ & $\begin{array}{c}0.433 * * \\
(0.204)\end{array}$ & $\begin{array}{c}0.304 \\
(0.304)\end{array}$ & $\begin{array}{l}0.661^{*} \\
(0.397)\end{array}$ & $\begin{array}{c}0.369^{*} \\
(0.190)\end{array}$ \\
\hline E. + Economic Controls & $\begin{array}{c}0.605 * * * \\
(0.201)\end{array}$ & $\begin{array}{c}0.115 \\
(0.256)\end{array}$ & $\begin{array}{l}0.462^{*} \\
(0.239)\end{array}$ & $\begin{array}{l}0.409^{*} \\
(0.215)\end{array}$ & $\begin{array}{c}0.319 \\
(0.323)\end{array}$ & $\begin{array}{c}0.639 \\
(0.470)\end{array}$ & $\begin{array}{c}0.393 * * \\
(0.193)\end{array}$ \\
\hline F. + Decision Making Controls & $\begin{array}{c}0.610^{* * * *} \\
(0.205)\end{array}$ & $\begin{array}{c}0.175 \\
(0.258)\end{array}$ & $\begin{array}{c}0.515^{* *} \\
(0.244)\end{array}$ & $\begin{array}{c}0.423^{* *} \\
(0.214)\end{array}$ & $\begin{array}{c}0.347 \\
(0.330)\end{array}$ & $\begin{array}{l}0.746^{*} \\
(0.449)\end{array}$ & $\begin{array}{c}0.436^{* *} \\
(0.198)\end{array}$ \\
\hline $\mathrm{N}$ & 544 & 544 & 544 & 544 & 362 & 203 & 705 \\
\hline
\end{tabular}

Notes: Robust standard errors in parentheses. See notes to Table 4 for basic, time preference, demographic, economic, and decision making

control sets. In the final column, a dummy variable identifying polygamous couples is included in the demographic control set. ***, **, and

* indicate significance at the 99,95 , and 90 percent confidence levels respectively. 


\begin{tabular}{|c|c|c|c|c|c|c|}
\hline Outcome is: & $\begin{array}{c}\text { Saved - } \\
\text { Excluding } \\
\text { Cash Prizes }\end{array}$ & Open & $\begin{array}{l}\text { Average } \\
\text { Balance } \\
\text { (Level) }\end{array}$ & $\begin{array}{l}\text { Average } \\
\text { Balance } \\
(\text { Log }+1)\end{array}$ & $\begin{array}{l}\text { Number } \\
\text { Deposits }\end{array}$ & $\begin{array}{c}\text { Number } \\
\text { Transactions }\end{array}$ \\
\hline \multicolumn{7}{|c|}{ Panel A. Basic Controls } \\
\hline \multicolumn{7}{|c|}{ All Couples With Dominated Individual Accounts } \\
\hline Poorly Matched & $\begin{array}{l}0.056^{*} \\
(0.033)\end{array}$ & $\begin{array}{c}0.067 \\
(0.052)\end{array}$ & $\begin{array}{c}39.1 \\
(127)\end{array}$ & $\begin{array}{c}0.561 * * * \\
(0.232)\end{array}$ & $\begin{array}{l}0.347^{*} \\
(0.193)\end{array}$ & $\begin{array}{l}0.509^{*} \\
(0.271)\end{array}$ \\
\hline DV Mean (Well Matched) & 0.067 & 0.341 & 177 & 0.515 & 0.268 & 0.360 \\
\hline $\mathrm{N}$ & 331 & 331 & 331 & 331 & 331 & 331 \\
\hline \multicolumn{7}{|c|}{ Subset of Couples Who Saved in at Least One Account } \\
\hline Poorly Matched & $\begin{array}{c}0.143 * * \\
(0.073)\end{array}$ & $\begin{array}{c}0.217 * * * \\
(0.081)\end{array}$ & $\begin{array}{l}-18.4 \\
(353)\end{array}$ & $\begin{array}{l}1.05^{* *} \\
(0.516)\end{array}$ & $\begin{array}{c}0.570 \\
(0.389)\end{array}$ & $\begin{array}{c}0.878 \\
(0.558)\end{array}$ \\
\hline DV Mean (Well Matched) & 0.125 & 0.208 & 404 & 1.17 & 0.556 & 0.764 \\
\hline $\mathrm{N}$ & 147 & 147 & 147 & 147 & 147 & 147 \\
\hline \multicolumn{7}{|c|}{ Panel B. + Time Preference Controls } \\
\hline \multicolumn{7}{|c|}{ All Couples With Dominated Individual Accounts } \\
\hline Poorly Matched & $\begin{array}{c}0.083 * * * \\
(0.034)\end{array}$ & $\begin{array}{c}0.086 \\
(0.062)\end{array}$ & $\begin{array}{c}132 \\
(125)\end{array}$ & $\begin{array}{c}0.839 * * * \\
(0.247)\end{array}$ & $\begin{array}{c}0.500 * * * \\
(0.208)\end{array}$ & $\begin{array}{c}0.800 * * * \\
(0.324)\end{array}$ \\
\hline DV Mean (Well Matched) & 0.067 & 0.341 & 177 & 0.515 & 0.268 & 0.360 \\
\hline $\mathrm{N}$ & 331 & 331 & 331 & 331 & 331 & 331 \\
\hline \multicolumn{7}{|c|}{ Subset of Couples Who Saved in at Least One Account } \\
\hline Poorly Matched & $\begin{array}{c}0.195 * * * \\
(0.082)\end{array}$ & $\begin{array}{c}0.245^{* * *} \\
(0.099)\end{array}$ & $\begin{array}{c}277 \\
(394)\end{array}$ & $\begin{array}{l}1.72 * * * \\
(0.627)\end{array}$ & $\begin{array}{l}1.00 * * \\
(0.474)\end{array}$ & $\begin{array}{l}1.75 * * \\
(0.786)\end{array}$ \\
\hline DV Mean (Well Matched) & 0.125 & 0.208 & 404 & 1.17 & 0.556 & 0.764 \\
\hline $\mathrm{N}$ & 147 & 147 & 147 & 147 & 147 & 147 \\
\hline \multicolumn{7}{|c|}{ Panel C. + Demographic Controls } \\
\hline \multicolumn{7}{|c|}{ All Couples With Dominated Individual Accounts } \\
\hline Poorly Matched & $\begin{array}{l}0.066^{*} \\
(0.036)\end{array}$ & $\begin{array}{c}0.056 \\
(0.069)\end{array}$ & $\begin{array}{l}154^{*} \\
(93.3)\end{array}$ & $\begin{array}{c}0.755^{* * *} \\
(0.263)\end{array}$ & $\begin{array}{c}0.433^{* *} \\
(0.214)\end{array}$ & $\begin{array}{c}0.680^{* *} \\
(0.318)\end{array}$ \\
\hline DV Mean (Well Matched) & 0.067 & 0.341 & 177 & 0.515 & 0.268 & 0.360 \\
\hline $\mathrm{N}$ & 331 & 331 & 331 & 331 & 331 & 331 \\
\hline \multicolumn{7}{|c|}{ Subset of Couples Who Saved in at Least One Account } \\
\hline Poorly Matched & $\begin{array}{l}0.168^{*} \\
(0.100)\end{array}$ & $\begin{array}{c}0.247 * * \\
(0.123)\end{array}$ & $\begin{array}{l}524^{*} \\
(315)\end{array}$ & $\begin{array}{l}1.98 * * * \\
(0.767)\end{array}$ & $\begin{array}{c}1.07^{*} \\
(0.588)\end{array}$ & $\begin{array}{l}1.87 * * \\
(0.819)\end{array}$ \\
\hline DV Mean (Well Matched) & 0.125 & 0.208 & 404 & 1.17 & 0.556 & 0.764 \\
\hline $\mathrm{N}$ & 147 & 147 & 147 & 147 & 147 & 147 \\
\hline \multicolumn{7}{|c|}{ Panel D. + Economic and Decision Making Controls } \\
\hline Poorly Matched & $\begin{array}{l}0.072 * \\
(0.039)\end{array}$ & $\begin{array}{c}0.087 \\
(0.073)\end{array}$ & $\begin{array}{c}145 \\
(104)\end{array}$ & $\begin{array}{c}0.877 * * * \\
(0.304)\end{array}$ & $\begin{array}{l}0.414^{*} \\
(0.239)\end{array}$ & $\begin{array}{c}0.711 * * \\
(0.356)\end{array}$ \\
\hline DV Mean (Well Matched) & 0.067 & 0.341 & 177 & 0.515 & 0.268 & 0.360 \\
\hline $\mathrm{N}$ & 331 & 331 & 331 & 331 & 331 & 331 \\
\hline \multicolumn{7}{|c|}{ Subset of Couples Who Saved in at Least One Account } \\
\hline Poorly Matched & $\begin{array}{c}0.128 \\
(0.145)\end{array}$ & $\begin{array}{c}0.206 \\
(0.170)\end{array}$ & $\begin{array}{c}40.1 \\
(345)\end{array}$ & $\begin{array}{l}1.55 \\
(1.02)\end{array}$ & $\begin{array}{c}0.570 \\
(0.868)\end{array}$ & $\begin{array}{c}1.40 \\
(1.19)\end{array}$ \\
\hline DV Mean (Well Matched) & 0.125 & 0.208 & 404 & 1.17 & 0.556 & 0.764 \\
\hline $\mathrm{N}$ & 147 & 147 & 147 & 147 & 147 & 147 \\
\hline
\end{tabular}

Notes: Heteroskedasticity robust standard errors in parentheses. The sample is limited to the subset of couples for whom the joint account bears the highest interest rate. All regressions include basic, time preference, demographic, economic, and decision making controls sets as decribed by Table 4. ${ }^{* * *}, * *$, and * indicate significance at the 99,95 , and 90 percent confidence levels respectively. 
Appendix Table D8. Responses to the Excess Interest Rate by Match Quality - Altnernative Outcomes

\begin{tabular}{|c|c|c|c|c|c|c|}
\hline Outcome is: & $\begin{array}{c}\text { Saved - } \\
\text { Excluding } \\
\text { Cash Prizes }\end{array}$ & Opened & $\begin{array}{c}\text { Average } \\
\text { Balance } \\
\text { (level) }\end{array}$ & $\begin{array}{l}\text { Average } \\
\text { Balance } \\
(\log +1)\end{array}$ & $\begin{array}{l}\text { Number } \\
\text { Deposits }\end{array}$ & $\begin{array}{c}\text { Number } \\
\text { Transactions }\end{array}$ \\
\hline ס1: Well Matched $\times$ Excess Yes & $\begin{array}{c}0.009 \\
(0.006)\end{array}$ & $\begin{array}{c}0.014 \\
(0.009)\end{array}$ & $\begin{array}{c}11.1 \\
(11.8)\end{array}$ & $\begin{array}{c}0.095 * * * \\
(0.039)\end{array}$ & $\begin{array}{c}0.042 \\
(0.028)\end{array}$ & $\begin{array}{c}0.072 \\
(0.048)\end{array}$ \\
\hline 82: Well Matched $\times$ Excess No & $\begin{array}{c}0.005 \\
(0.005)\end{array}$ & $\begin{array}{c}0.013 \\
(0.008)\end{array}$ & $\begin{array}{c}27.9 \\
(18.2)\end{array}$ & $\begin{array}{c}0.026 \\
(0.034)\end{array}$ & $\begin{array}{c}0.046 \\
(0.031)\end{array}$ & $\begin{array}{c}0.078 \\
(0.054)\end{array}$ \\
\hline$\gamma 1$ : Poorly Matched $\times$ Excess Yes & $\begin{array}{l}-0.009 \\
(0.006)\end{array}$ & $\begin{array}{c}0.006 \\
(0.010)\end{array}$ & $\begin{array}{l}-6.75 \\
(14.5)\end{array}$ & $\begin{array}{c}0.005 \\
(0.042)\end{array}$ & $\begin{array}{l}-0.026 \\
(0.023)\end{array}$ & $\begin{array}{l}-0.035 \\
(0.042)\end{array}$ \\
\hline$\gamma 2$ : Poorly Matched $\times$ Excess No & $\begin{array}{l}-0.005 \\
(0.005)\end{array}$ & $\begin{array}{c}0.004 \\
(0.009)\end{array}$ & $\begin{array}{l}-11.9 \\
(11.1)\end{array}$ & $\begin{array}{l}-0.047 \\
(0.039)\end{array}$ & $\begin{array}{c}0.009 \\
(0.044)\end{array}$ & $\begin{array}{c}0.001 \\
(0.063)\end{array}$ \\
\hline$\beta 1$ : Poorly Matched & $\begin{array}{l}-0.034 \\
(0.051)\end{array}$ & $\begin{array}{l}-0.084 \\
(0.107)\end{array}$ & $\begin{array}{l}-215 \\
(149)\end{array}$ & $\begin{array}{l}-0.200 \\
(0.381)\end{array}$ & $\begin{array}{l}-0.186 \\
(0.376)\end{array}$ & $\begin{array}{l}-0.358 \\
(0.579)\end{array}$ \\
\hline P-value from F-test: $\delta 1=\gamma 1$ & $0.032 * *$ & 0.533 & 0.334 & 0.117 & $0.062 *$ & $0.095^{*}$ \\
\hline P-value from F-test: $\delta 2=\gamma 2$ & 0.201 & 0.477 & $0.063^{*}$ & 0.160 & 0.481 & 0.349 \\
\hline P-value from F-test: $\delta 1=\gamma 1 \& \delta 2=\gamma 2$ & $0.029 * *$ & 0.413 & $0.070 *$ & $0.050 *$ & $0.068 *$ & $0.084 *$ \\
\hline DV Mean (Well Matched) & 0.094 & 0.484 & 144 & 0.898 & 0.360 & 0.526 \\
\hline $\mathrm{N}$ & 1632 & 1632 & 1632 & 1632 & 1632 & 1632 \\
\hline Control Set & Decisions & Decisions & Decisions & Decisions & Decisions & Decisions \\
\hline
\end{tabular}

Notes: Data is at the account level. Robust standard errors clustered at the couple level in parentheses. All regressions include the basic through decision making control sets. See notes to Table 5 for additional detail on the included control sets. $* * *, * *$, and $*$ indicate significance at the 99,95 , and 90 percent confidence levels respectively. 
Appendix Table D9. Balance Check - Reweighted Sample

\begin{tabular}{|c|c|c|c|c|c|c|}
\hline & \multicolumn{5}{|c|}{ Treatment } & \multirow[b]{3}{*}{$\mathrm{N}$} \\
\hline & \multicolumn{3}{|c|}{ Excess Interest Rate } & \multirow{2}{*}{$\begin{array}{c}\text { Extra } \\
\text { Statements }\end{array}$} & \multirow{2}{*}{$\begin{array}{c}\text { Cash } \\
\text { Payment }\end{array}$} & \\
\hline & Husband & Wife & Joint & & & \\
\hline Marital Status Confirmed & $\begin{array}{c}0.001 \\
(0.003)\end{array}$ & $\begin{array}{c}-0.002 \\
(0.002)\end{array}$ & $\begin{array}{l}-0.001 \\
(0.003)\end{array}$ & $\begin{array}{l}-0.007 \\
(0.017)\end{array}$ & $\begin{array}{c}0.008 \\
(0.012)\end{array}$ & 1196 \\
\hline Age & $\begin{array}{c}0.084 \\
(0.229)\end{array}$ & $\begin{array}{l}-0.006 \\
(0.231)\end{array}$ & $\begin{array}{c}0.091 \\
(0.240)\end{array}$ & $\begin{array}{l}-0.470 \\
(1.27)\end{array}$ & $\begin{array}{c}1.21 \\
(1.10)\end{array}$ & 1088 \\
\hline Education & $\begin{array}{l}-0.050 \\
(0.055)\end{array}$ & $\begin{array}{l}-0.094 \\
(0.058)\end{array}$ & $\begin{array}{l}-0.051 \\
(0.061)\end{array}$ & $\begin{array}{c}0.287 \\
(0.332)\end{array}$ & $\begin{array}{l}-0.109 \\
(0.326)\end{array}$ & 1084 \\
\hline Literate & $\begin{array}{l}-0.003 \\
(0.005)\end{array}$ & $\begin{array}{l}-0.001 \\
(0.006)\end{array}$ & $\begin{array}{c}0.002 \\
(0.007)\end{array}$ & $\begin{array}{c}0.008 \\
(0.033)\end{array}$ & $\begin{array}{c}0.007 \\
(0.035)\end{array}$ & 1088 \\
\hline Number Children & $\begin{array}{c}0.029 \\
(0.040)\end{array}$ & $\begin{array}{l}-0.001 \\
(0.043)\end{array}$ & $\begin{array}{c}0.023 \\
(0.045)\end{array}$ & $\begin{array}{c}0.282 \\
(0.237)\end{array}$ & $\begin{array}{c}0.150 \\
(0.232)\end{array}$ & 1088 \\
\hline Subsistence Farmer/No Job & $\begin{array}{c}0.004 \\
(0.007)\end{array}$ & $\begin{array}{c}0.006 \\
(0.007)\end{array}$ & $\begin{array}{c}0.007 \\
(0.008)\end{array}$ & $\begin{array}{l}-0.009 \\
(0.041)\end{array}$ & $\begin{array}{c}0.007 \\
(0.044)\end{array}$ & 1084 \\
\hline Distance from Bank (Miles) & $\begin{array}{c}0.034 \\
(0.036)\end{array}$ & $\begin{array}{c}0.009 \\
(0.037)\end{array}$ & $\begin{array}{c}0.021 \\
(0.043)\end{array}$ & $\begin{array}{l}-0.024 \\
(0.229)\end{array}$ & $\begin{array}{l}-0.064 \\
(0.162)\end{array}$ & 1088 \\
\hline Income Last Week & $\begin{array}{l}-5.24 \\
(25.3)\end{array}$ & $\begin{array}{l}-13.7 \\
(23.4)\end{array}$ & $\begin{array}{l}-11.1 \\
(23.4)\end{array}$ & $\begin{array}{c}121 \\
(150)\end{array}$ & $\begin{array}{c}-412 * * * \\
(108)\end{array}$ & 1057 \\
\hline Owns Mobile Phone & $\begin{array}{l}-0.003 \\
(0.007)\end{array}$ & $\begin{array}{l}-0.003 \\
(0.008)\end{array}$ & $\begin{array}{l}-0.001 \\
(0.009)\end{array}$ & $\begin{array}{c}0.057 \\
(0.043)\end{array}$ & $\begin{array}{c}0.012 \\
(0.042)\end{array}$ & 1083 \\
\hline Participates in ROSCA & $\begin{array}{c}0.000 \\
(0.007)\end{array}$ & $\begin{array}{c}0.009 \\
(0.007)\end{array}$ & $\begin{array}{c}0.012 \\
(0.008)\end{array}$ & $\begin{array}{c}0.023 \\
(0.038)\end{array}$ & $\begin{array}{c}0.001 \\
(0.044)\end{array}$ & 1088 \\
\hline Has Bank Account & $\begin{array}{c}0.001 \\
(0.005)\end{array}$ & $\begin{array}{l}-0.005 \\
(0.005)\end{array}$ & $\begin{array}{c}0.000 \\
(0.006)\end{array}$ & $\begin{array}{c}0.006 \\
(0.030)\end{array}$ & $\begin{array}{c}0.030 \\
(0.035)\end{array}$ & 1088 \\
\hline Has a SACCO Account & $\begin{array}{l}-0.001 \\
(0.002)\end{array}$ & $\begin{array}{l}-0.003 \\
(0.002)\end{array}$ & $\begin{array}{l}-0.002 \\
(0.002)\end{array}$ & $\begin{array}{c}0.003 \\
(0.013)\end{array}$ & $\begin{array}{c}0.002 \\
(0.015)\end{array}$ & 1086 \\
\hline Saves at Home & $\begin{array}{l}-0.001 \\
(0.004)\end{array}$ & $\begin{array}{c}0.002 \\
(0.004)\end{array}$ & $\begin{array}{l}-0.006 \\
(0.005)\end{array}$ & $\begin{array}{l}-0.010 \\
(0.027)\end{array}$ & $\begin{array}{c}0.040 \\
(0.026)\end{array}$ & 1087 \\
\hline Has Mobile Money Account & $\begin{array}{l}-0.001 \\
(0.006)\end{array}$ & $\begin{array}{c}0.000 \\
(0.006)\end{array}$ & $\begin{array}{c}0.001 \\
(0.006)\end{array}$ & $\begin{array}{l}-0.001 \\
(0.031)\end{array}$ & $\begin{array}{l}-0.012 \\
(0.037)\end{array}$ & 918 \\
\hline Saves Other Ways & $\begin{array}{c}0.010 \\
(0.007)\end{array}$ & $\begin{array}{c}0.009 \\
(0.008)\end{array}$ & $\begin{array}{c}0.005 \\
(0.008)\end{array}$ & $\begin{array}{c}0.051 \\
(0.037)\end{array}$ & $\begin{array}{l}-0.053 \\
(0.047)\end{array}$ & 918 \\
\hline Total Reported Savings & $\begin{array}{c}360 \\
(443)\end{array}$ & $\begin{array}{l}91.6 \\
(508)\end{array}$ & $\begin{array}{l}-274 \\
(373)\end{array}$ & $\begin{array}{c}2395 \\
(4059)\end{array}$ & $\begin{array}{c}8159 \\
(9441)\end{array}$ & 851 \\
\hline Weekly Discount Factor & $\begin{array}{l}-0.001 \\
(0.005)\end{array}$ & $\begin{array}{l}-0.003 \\
(0.005)\end{array}$ & $\begin{array}{l}-0.005 \\
(0.005)\end{array}$ & $\begin{array}{l}0.050^{*} \\
(0.026)\end{array}$ & $\begin{array}{l}-0.056^{*} \\
(0.034)\end{array}$ & 1088 \\
\hline Impatient Now-Patient Later & $\begin{array}{l}-0.004 \\
(0.005)\end{array}$ & $\begin{array}{l}-0.001 \\
(0.005)\end{array}$ & $\begin{array}{l}-0.002 \\
(0.006)\end{array}$ & $\begin{array}{l}-0.015 \\
(0.030)\end{array}$ & $\begin{array}{c}-0.074 * * * \\
(0.031)\end{array}$ & 1070 \\
\hline Patient Now-Impatient Later & $\begin{array}{c}0.003 \\
(0.005)\end{array}$ & $\begin{array}{c}0.002 \\
(0.006)\end{array}$ & $\begin{array}{l}-0.001 \\
(0.006)\end{array}$ & $\begin{array}{c}0.051 \\
(0.031)\end{array}$ & $\begin{array}{c}0.016 \\
(0.040)\end{array}$ & 1070 \\
\hline Well Matched Couple & $\begin{array}{l}-0.005 \\
(0.009)\end{array}$ & $\begin{array}{l}-0.014 \\
(0.009)\end{array}$ & $\begin{array}{l}-0.012 \\
(0.010)\end{array}$ & $\begin{array}{l}-0.046 \\
(0.052)\end{array}$ & $\begin{array}{c}0.048 \\
(0.041)\end{array}$ & 1088 \\
\hline Consumption - Husband Decides & $\begin{array}{c}0.004 \\
(0.006)\end{array}$ & $\begin{array}{l}-0.006 \\
(0.007)\end{array}$ & $\begin{array}{c}0.001 \\
(0.008)\end{array}$ & $\begin{array}{l}-0.010 \\
(0.037)\end{array}$ & $\begin{array}{c}0.023 \\
(0.043)\end{array}$ & 1083 \\
\hline Consumption - Wife Decides & $\begin{array}{c}0.001 \\
(0.004)\end{array}$ & $\begin{array}{c}0.004 \\
(0.004)\end{array}$ & $\begin{array}{c}0.000 \\
(0.004)\end{array}$ & $\begin{array}{l}-0.021 \\
(0.023)\end{array}$ & $\begin{array}{c}0.021 \\
(0.028)\end{array}$ & 1083 \\
\hline Consumption - Both Decide & $\begin{array}{l}-0.006 \\
(0.006)\end{array}$ & $\begin{array}{c}0.000 \\
(0.007)\end{array}$ & $\begin{array}{l}-0.001 \\
(0.007)\end{array}$ & $\begin{array}{c}0.007 \\
(0.037)\end{array}$ & $\begin{array}{l}-0.037 \\
(0.041)\end{array}$ & 1083 \\
\hline Saving - Husband Mostly Saves & $\begin{array}{l}-0.002 \\
(0.006)\end{array}$ & $\begin{array}{c}0.002 \\
(0.006)\end{array}$ & $\begin{array}{c}0.002 \\
(0.006)\end{array}$ & $\begin{array}{l}-0.021 \\
(0.033)\end{array}$ & $\begin{array}{l}-0.039 \\
(0.040)\end{array}$ & 1082 \\
\hline Saving - Wife Mostly Saves & $\begin{array}{c}0.000 \\
(0.006)\end{array}$ & $\begin{array}{l}-0.011 \\
(0.007)\end{array}$ & $\begin{array}{l}-0.012 \\
(0.008)\end{array}$ & $\begin{array}{c}0.011 \\
(0.039)\end{array}$ & $\begin{array}{c}0.053 \\
(0.044)\end{array}$ & 1082 \\
\hline Saving - Both Save & $\begin{array}{c}0.001 \\
(0.005)\end{array}$ & $\begin{array}{c}0.008 \\
(0.005)\end{array}$ & $\begin{array}{c}0.009 \\
(0.006)\end{array}$ & $\begin{array}{c}0.007 \\
(0.031)\end{array}$ & $\begin{array}{l}-0.019 \\
(0.034)\end{array}$ & 1082 \\
\hline Decision Error: Standard Deviation & $\begin{array}{l}-0.151 \\
(0.385)\end{array}$ & $\begin{array}{l}-0.322 \\
(0.466)\end{array}$ & $\begin{array}{l}-0.575 \\
(0.516)\end{array}$ & $\begin{array}{l}-0.116 \\
(2.59)\end{array}$ & $\begin{array}{c}1.15 \\
(3.12)\end{array}$ & 1088 \\
\hline Spouses Disagree: Consumption & $\begin{array}{c}-0.017 * * \\
(0.008)\end{array}$ & $\begin{array}{c}-0.018^{* *} \\
(0.009)\end{array}$ & $\begin{array}{l}-0.010 \\
(0.010)\end{array}$ & $\begin{array}{l}-0.023 \\
(0.051)\end{array}$ & $\begin{array}{l}-0.007 \\
(0.042)\end{array}$ & 1078 \\
\hline Spouses Disagree: Saving & $\begin{array}{c}0.005 \\
(0.008)\end{array}$ & $\begin{array}{c}0.009 \\
(0.009)\end{array}$ & $\begin{array}{l}0.018^{*} \\
(0.010)\end{array}$ & $\begin{array}{l}-0.065 \\
(0.051)\end{array}$ & $\begin{array}{c}0.052 \\
(0.041)\end{array}$ & 1076 \\
\hline Poorly Informed Couple & $\begin{array}{c}0.003 \\
(0.009)\end{array}$ & $\begin{array}{c}0.001 \\
(0.009)\end{array}$ & $\begin{array}{c}0.015 \\
(0.010)\end{array}$ & $\begin{array}{l}-0.042 \\
(0.054)\end{array}$ & $\begin{array}{c}-0.079^{*} \\
(0.045)\end{array}$ & 944 \\
\hline P-vlaue: Joint Test (Cross Equation) & 0.919 & 0.187 & 0.773 & 0.409 & $0.002 * * *$ & \\
\hline
\end{tabular}

Notes: Standard errors clustered at the couple level are in parentheses. Each row presents the results of a regression of observable characteristics on all listed treatments of interest (rows correspond to a single regression). All regressions also include a dummy variable identifying couples ineligible for the extra statements treatment. Excess interest rate variables range from -10 to 10 . Mobile money and other savings data not available for the 84 couples in the first 6 experimental sessions. Variables are recoded to missing if response was don't know/refused. P-values from the joint test are calculated by jointly estimating equations by seemingly unrelated regression. ***, **, and * indicate significance at the 99,95 , and 90 percent confidence levels respectively. 


\begin{tabular}{|c|c|c|c|c|c|}
\hline \multicolumn{6}{|c|}{ Panel A. All Couples With Dominated Individual Accounts } \\
\hline Poorly Matched & $\begin{array}{c}0.082 * * \\
(0.037)\end{array}$ & $\begin{array}{c}0.121^{* * *} \\
(0.041)\end{array}$ & $\begin{array}{c}0.110 * * * \\
(0.045)\end{array}$ & $\begin{array}{c}0.138 * * * \\
(0.048)\end{array}$ & $\begin{array}{c}0.145 * * * \\
(0.050)\end{array}$ \\
\hline Poorly Informed & & & & & $\begin{array}{c}0.063 \\
(0.043)\end{array}$ \\
\hline Decision Error: Husband & & & & & $\begin{array}{c}0.000 \\
(0.001)\end{array}$ \\
\hline Decision Error: Wife & & & & & $\begin{array}{c}0.001 \\
(0.001)\end{array}$ \\
\hline Spouses Disagree: Consumption & & & & & $\begin{array}{c}0.008 \\
(0.047)\end{array}$ \\
\hline Spouses Disagree: Saving & & & & & $\begin{array}{l}-0.059 \\
(0.043)\end{array}$ \\
\hline DV Mean (Well Matched) & 0.084 & 0.084 & 0.084 & 0.084 & 0.084 \\
\hline $\mathrm{N}$ & 331 & 331 & 331 & 331 & 331 \\
\hline \multicolumn{6}{|c|}{ Panel B. Subset of Couples Who Saved in at Least One Account } \\
\hline Poorly Matched & $\begin{array}{l}0.144^{*} \\
(0.086)\end{array}$ & $\begin{array}{c}0.193^{*} \\
(0.108)\end{array}$ & $\begin{array}{c}0.321 * * \\
(0.138)\end{array}$ & $\begin{array}{c}0.304 * * \\
(0.139)\end{array}$ & $\begin{array}{c}0.274 \\
(0.185)\end{array}$ \\
\hline Poorly Informed & & & & & $\begin{array}{c}0.144 \\
(0.171)\end{array}$ \\
\hline Decision Error: Husband & & & & & $\begin{array}{c}0.000 \\
(0.001)\end{array}$ \\
\hline Decision Error: Wife & & & & & $\begin{array}{c}0.003 \\
(0.002)\end{array}$ \\
\hline Spouses Disagree: Consumption & & & & & $\begin{array}{l}-0.090 \\
(0.140)\end{array}$ \\
\hline Spouses Disagree: Saving & & & & & $\begin{array}{l}-0.087 \\
(0.131)\end{array}$ \\
\hline DV Mean (Well Matched) & 0.211 & 0.211 & 0.211 & 0.211 & 0.211 \\
\hline $\mathrm{N}$ & 147 & 147 & 147 & 147 & 147 \\
\hline Control Set & Basic & +Time Pref & +Demo. & +Economic & + Decisions \\
\hline
\end{tabular}

Notes: The sample is limited to the subset of couples for whom the joint account bears the highest interest rate. The dependent variable is a dummy indicating that a couple saved in any individual account. Heteroskedasticity robust standard errors in parentheses. See notes to Table 4 for additional details, including control sets. ${ }^{* * *}, * *$, and * indicate significance at the 99,95 , and 90 percent confidence levels respectively. 
Appendix Table D11. Responses to the Excess Interest Rate by Match Quality - Reweighted Sample

\begin{tabular}{lccccc}
\hline \hline$\delta_{1}$ : Well Matched $\times$ Excess Yes & $0.014^{*}$ & $0.017^{* * *}$ & $0.016^{* *}$ & $0.014^{*}$ & $0.014^{*}$ \\
& $(0.008)$ & $(0.007)$ & $(0.007)$ & $(0.008)$ & $(0.009)$ \\
$\delta_{2}$ : Well Matched $\times$ Excess No & -0.002 & -0.002 & 0.005 & 0.004 & 0.003 \\
& $(0.006)$ & $(0.006)$ & $(0.007)$ & $(0.007)$ & $(0.008)$ \\
$\gamma_{1}$ : Poorly Matched $\times$ Excess Yes & -0.003 & 0.002 & 0.006 & 0.002 & -0.004 \\
& $(0.007)$ & $(0.010)$ & $(0.012)$ & $(0.013)$ & $(0.015)$ \\
$\gamma_{2}$ : Poorly Matched $\times$ Excess No & -0.004 & -0.013 & -0.013 & -0.007 & -0.007 \\
& $(0.007)$ & $(0.009)$ & $(0.011)$ & $(0.012)$ & $(0.014)$ \\
$\beta_{1}$ : Poorly Matched & 0.035 & -0.018 & -0.068 & -0.017 & 0.005 \\
& $(0.073)$ & $(0.080)$ & $(0.096)$ & $(0.114)$ & $(0.126)$ \\
P-value from F-test: $\delta_{1}=\gamma_{1}$ & $0.098^{*}$ & 0.214 & 0.528 & 0.443 & 0.290 \\
P-value from F-test: $\delta_{2}=\gamma_{2}$ & 0.827 & 0.319 & 0.157 & 0.447 & 0.557 \\
P-value from F-test: $\delta_{1}=\gamma_{1} \& \delta_{2}=\gamma_{2}$ & 0.220 & 0.202 & 0.207 & 0.456 & 0.397 \\
DV Mean $($ Well Matched) & 0.155 & 0.155 & 0.155 & 0.155 & 0.155 \\
$\mathrm{~N}$ & 1632 & 1632 & 1632 & 1632 & 1632 \\
Control Set & Basic & + Time Pref & + Demo. & + Economic & + Decisions \\
\hline
\end{tabular}

Notes: Data is at the account level. The dependent variable is a dummy indicating that an account received a savings deposit. Robust standard errors clustered at the couple level in parentheses. See notes to Table 5 for control sets and additional specification details. ***,**, and $*$ indicate significance at the 99, 95, and 90 percent confidence levels respectively. 
Appendix Table D12. Interest Rate Losses by Match Quality - Reweighted Sample

\begin{tabular}{|c|c|c|c|c|c|c|c|}
\hline \multirow[b]{2}{*}{ Maximum Individual Discount } & \multirow{2}{*}{$\begin{array}{c}\text { No } \\
\text { Discounting }\end{array}$} & \multicolumn{3}{|c|}{ Proxied Banking Cost Discounting } & \multicolumn{3}{|c|}{ Uniform Discounting } \\
\hline & & 5 & 10 & 15 & 5 & 10 & 15 \\
\hline \multicolumn{8}{|l|}{ Poorly Matched Couples } \\
\hline Maximum Interest Earnings & 8.08 & 6.65 & 6.13 & 6.07 & 6.41 & 6.05 & 6.05 \\
\hline Actual Interest Earnings & 7.08 & 5.77 & 4.95 & 4.37 & 5.44 & 4.47 & 3.71 \\
\hline Loss & 0.997 & 0.885 & 1.18 & 1.69 & 0.978 & 1.57 & 2.34 \\
\hline \multicolumn{8}{|l|}{ Well Matched Couples } \\
\hline Maximum Interest Earnings & 8.09 & 6.62 & 6.00 & 5.88 & 6.33 & 5.86 & 5.86 \\
\hline Actual Interest Earnings & 7.43 & 6.12 & 5.30 & 4.87 & 5.74 & 4.82 & 4.24 \\
\hline Loss & 0.665 & 0.500 & 0.703 & 1.01 & 0.586 & 1.04 & 1.62 \\
\hline \multicolumn{8}{|l|}{ Loss Gap } \\
\hline \multirow[t]{2}{*}{ A. No Controls } & $0.332 *$ & $0.385 * *$ & $0.473 *$ & $0.685^{*}$ & $0.391 *$ & 0.532 & 0.720 \\
\hline & $(0.185)$ & $(0.187)$ & $(0.259)$ & $(0.353)$ & $(0.209)$ & $(0.331)$ & $(0.472)$ \\
\hline \multirow[t]{2}{*}{ B. + Basic Controls } & $0.352 * *$ & $0.406 * *$ & $0.509 * *$ & $0.737 * *$ & $0.412 * *$ & $0.574 *$ & $0.789 *$ \\
\hline & $(0.171)$ & $(0.182)$ & $(0.254)$ & $(0.346)$ & $(0.206)$ & $(0.326)$ & $(0.464)$ \\
\hline \multirow[t]{2}{*}{ C. + Time Preference Controls } & $0.503 * * *$ & $0.560 * * *$ & $0.775 * * *$ & $1.12 * * *$ & $0.614 * * *$ & $0.944 * * *$ & $1.35 * * *$ \\
\hline & $(0.214)$ & $(0.205)$ & $(0.277)$ & $(0.377)$ & $(0.224)$ & $(0.351)$ & $(0.505)$ \\
\hline \multirow[t]{2}{*}{ D. + Demographic Controls } & $0.528 * * *$ & $0.567 * * *$ & $0.784 * * *$ & $1.14 * * *$ & $0.625 * * *$ & $0.961 * * *$ & $1.37 * * *$ \\
\hline & $(0.219)$ & $(0.220)$ & $(0.302)$ & $(0.406)$ & $(0.242)$ & $(0.377)$ & $(0.536)$ \\
\hline \multirow[t]{2}{*}{ E. + Economic Controls } & $0.546 * * *$ & $0.582 * * *$ & $0.801 * * *$ & $1.15 * * *$ & $0.635 * * *$ & $0.977 * * *$ & $1.40 * * *$ \\
\hline & $(0.222)$ & $(0.221)$ & $(0.304)$ & $(0.409)$ & $(0.242)$ & $(0.378)$ & $(0.536)$ \\
\hline \multirow[t]{2}{*}{ E. + Decision Making Controls } & $0.587 * * *$ & $0.601 * * *$ & $0.799 * * *$ & $1.14 * * *$ & $0.658 * * *$ & $0.992 * * *$ & $1.41 * * *$ \\
\hline & $(0.228)$ & $(0.227)$ & $(0.310)$ & $(0.418)$ & $(0.248)$ & $(0.386)$ & $(0.548)$ \\
\hline $\mathrm{N}$ & 544 & 544 & 544 & 544 & 544 & 544 & 544 \\
\hline
\end{tabular}

Notes: Heteroskedasticity robust standard errors in parentheses. See notes to Table 6 for specification details, including control sets. $* * *, * *$, and $*$ indicate significance at the 99,95 , and 90 percent confidence levels respectively. 


\section{Appendix Figure D1. Interest Rate Design}

\begin{tabular}{|c|c|c|c|c|c|c|c|c|c|c|c|c|c|}
\hline \hline \multicolumn{7}{|c|}{$\mathrm{R}_{\mathrm{J}}=2$} \\
\hline & $\mathrm{R}_{\mathrm{M}}=0$ & $\mathrm{R}_{\mathrm{M}}=2$ & $\mathrm{R}_{\mathrm{M}}=6$ & $\mathrm{R}_{\mathrm{M}}=10$ \\
\hline & 2, & 0, & -4, & -8, \\
$\mathrm{R}_{\mathrm{F}}=0$ & $-2,-2$ & $0,-2$ & $4,-6$ & $8,-10$ \\
\hline
\end{tabular}

Notes: The first number in interior cells is the excess interest rate on the joint account. The excess interest rate on the husband's and wife's account follow respectively. 